\title{
Pulmonary vascular and right ventricular dysfunction in adult critical care: current and emerging options for management: a systematic literature review
}

\author{
Laura C Price ${ }^{1 *}$, Stephen J Wort ${ }^{1+}$, Simon J Finney ${ }^{1}$, Philip S Marino ${ }^{1}$, Stephen J Brett ${ }^{2}$
}

\begin{abstract}
Introduction: Pulmonary vascular dysfunction, pulmonary hypertension $(\mathrm{PH})$, and resulting right ventricular (RV) failure occur in many critical illnesses and may be associated with a worse prognosis. PH and RV failure may be difficult to manage: principles include maintenance of appropriate RV preload, augmentation of RV function, and reduction of RV afterload by lowering pulmonary vascular resistance (PVR). We therefore provide a detailed update on the management of $\mathrm{PH}$ and $\mathrm{RV}$ failure in adult critical care.
\end{abstract}

Methods: A systematic review was performed, based on a search of the literature from 1980 to 2010, by using prespecified search terms. Relevant studies were subjected to analysis based on the GRADE method.

Results: Clinical studies of intensive care management of pulmonary vascular dysfunction were identified, describing volume therapy, vasopressors, sympathetic inotropes, inodilators, levosimendan, pulmonary vasodilators, and mechanical devices. The following GRADE recommendations (evidence level) are made in patients with pulmonary vascular dysfunction: 1) A weak recommendation (very-low-quality evidence) is made that close monitoring of the RV is advised as volume loading may worsen RV performance; 2) A weak recommendation (lowquality evidence) is made that low-dose norepinephrine is an effective pressor in these patients; and that 3) lowdose vasopressin may be useful to manage patients with resistant vasodilatory shock. 4) A weak recommendation (low-moderate quality evidence) is made that low-dose dobutamine improves RV function in pulmonary vascular dysfunction. 5) A strong recommendation (moderate-quality evidence) is made that phosphodiesterase type III inhibitors reduce PVR and improve RV function, although hypotension is frequent. 6) A weak recommendation (low-quality evidence) is made that levosimendan may be useful for short-term improvements in RV performance. 7) A strong recommendation (moderate-quality evidence) is made that pulmonary vasodilators reduce PVR and improve RV function, notably in pulmonary vascular dysfunction after cardiac surgery, and that the side-effect profile is reduced by using inhaled rather than systemic agents. 8) A weak recommendation (very-low-quality evidence) is made that mechanical therapies may be useful rescue therapies in some settings of pulmonary vascular dysfunction awaiting definitive therapy.

Conclusions: This systematic review highlights that although some recommendations can be made to guide the critical care management of pulmonary vascular and right ventricular dysfunction, within the limitations of this review and the GRADE methodology, the quality of the evidence base is generally low, and further high-quality research is needed.

\footnotetext{
* Correspondence: I.price@imperial.ac.uk

† Contributed equally

'Department of Critical Care, National Heart and Lung Institute, Imperial College London, Royal Brompton Hospital, Sydney Street, London SW3 6NP, UK

Full list of author information is available at the end of the article
} 


\section{Introduction}

Pulmonary vascular dysfunction is a broad term and may be central to several disease processes in the intensive care unit (ICU). Components include pulmonary endothelial dysfunction, altered lung microvascular permeability, vasoactive mediator imbalance, abnormal hypoxic vasoconstriction, pulmonary metabolic failure, microvascular thrombosis, and later, vascular remodelling [1-3]. The resulting elevation in pulmonary vascular resistance (PVR) and pulmonary hypertension (PH) may increase the transpulmonary gradient, and the right ventricular "pressure overload" can in turn result in right ventricular (RV) dysfunction and failure [4]. RV dysfunction may also result from volume overload or a primary RV pathology reducing contractility, including RV infarction and sepsis (Table 1) [4-7].

$\mathrm{PH}$ is defined at right-heart catheterization in the outpatient setting, with resting mPAP exceeding $25 \mathrm{~mm}$ $\mathrm{Hg}$, and a PVR greater than 240 dyn.s. $\mathrm{cm}^{-5}$ (3 Wood units) [8]. At echocardiography, the presence of $\mathrm{PH}$ is suggested by the estimated RV systolic pressure (RVSP) exceeding $35 \mathrm{~mm} \mathrm{Hg}$ (being severe if $>50 \mathrm{~mm} \mathrm{Hg}$ ) (see later) [9], and the pulmonary arterial acceleration time (PAT) may be shortened [10]. Pulmonary arterial hypertension (PAH) defines $\mathrm{PH}$ not due to left-heart disease, with PAOP $<15 \mathrm{~mm} \mathrm{Hg}$ or without echocardiographic evidence of increased left atrial pressure. The severity of PH may depend on the chronicity: the actual pulmonary artery pressure generated will increase with time as the RV hypertrophies.

RV dysfunction describes reduced RV contractility, which may be detected in several ways. At echocardiography, RV distention causes the intraventricular septum to deviate, with resulting paradoxic septal movement that impinges on LV function [11]. RV function may be difficult to assess on echocardiography, especially in ventilated patients, and measurement of the descent of the RV base toward the apex (tricuspid annular systolic excursion, TAPSE) or RV fractional shortening may useful $[12,13]$. Invasive monitoring may show a CVP exceeding the PAOP, or increasing CVP and PVR with a decreasing cardiac output (and MPAP may therefore decrease), and high right ventricular end-diastolic filling pressure is characteristic. By using an RV ejection fraction (RVEF) PAC, an increase in RV end-diastolic index and a reduction in RVEF are seen [14]. We have defined $\mathrm{RV}$ failure to be the clinical result of RV dysfunction with the onset of hypotension or any resulting endorgan (for example, renal, liver, or gastrointestinal) dysfunction. Acute cor pulmonale (ACP) refers to acute right heart failure in the setting of acutely elevated PVR due to pulmonary disease $[15,16]$.

Pulmonary hypertension per se is frequently encountered in the ICU. It is commonly due to elevated pulmonary venous pressure in the setting of left-sided heart disease, or in patients with preexisting pulmonary vascular disease. It is well recognized after cardiothoracic surgery, in part related to the endothelial dysfunction seen with cardiopulmonary bypass (CPB) $[17,18]$. $\mathrm{PH}$ is also associated with sepsis [19]; acute respiratory distress syndrome (ARDS) [20-22] (with associated acute RV failure in $10 \%$ to $25 \%$ of cases $[23,24]$ ), and in up to $60 \%$ of patients after massive pulmonary embolism (PE) [25]. PH is important to recognize in the ICU because its presence predicts increased mortality in these conditions [19,23,25-31] as well as after surgical procedures [32-42]. Mortality from cardiogenic shock due to RV infarction $(>50 \%)$ exceeds that due to LV disease [5]. We therefore thought that a systematic review of the current evidence for the management of $\mathrm{PH}$, resulting RV dysfunction, and failure in adult patients in the ICU, would be a useful addition to the critical care literature.

\section{The pulmonary circulation and pathophysiology of right ventricular failure}

The normal pulmonary circulation is a high-flow, lowpressure system. Unlike the left ventricle (LV), the thinwalled right ventricle tolerates poorly acute increases in

Table 1 Causes of pulmonary hypertension and right ventricle failure in the ICU

Causes of pulmonary hypertension in ICU
1) PAH (for example, preexisting PAH; PoPH (8.5\% ESLD)
2) Elevated LAP: RV pressure overload (left-sided myocardial infarction/
cardiomyopathy; mitral regurgitation; pulmonary stenosis)
3) PH due to hypoxia: acute (for example, ARDS)/preexisting lung
disease (for example, COPD, IPF)
4) Thromboembolic (for example, acute PE; chronic (CTEPH); other
causes of emboli (AFE, air, cement)
5) Mechanical (for example, increased Pplat - IPPV

\section{Causes of RV failure in ICU}

1) RV Pressure overload, pulmonary hypertension, any cause

2) Reduced RV contractility

RV infarction; sepsis; RV cardiomyopathy; myocarditis; pericardial disease; LVAD; after CPB; after cardiac surgery/transplantation

3) RV-volume overload

Cardiac causes: tricuspid and pulmonary regurgitation; intracardiac shunts

AFE, amniotic fluid embolus; ARDS, acute respiratory distress syndrome; COPD, chronic obstructive pulmonary disease; CPB, cardiopulmonary bypass; CTEPH, chronic thromboembolic pulmonary hypertension; ESLD, end-stage liver disease; IPF, idiopathic pulmonary fibrosis; IPPV, intermittent positive-pressure ventilation; LAP, left atrial pressure; LVAD, left ventricular assist device; PAH, pulmonary arterial hypertension; PoPH, portopulmonary hypertension; $\mathrm{P}_{\text {plat, }}$ plateau pressure; RV, right ventricle. 


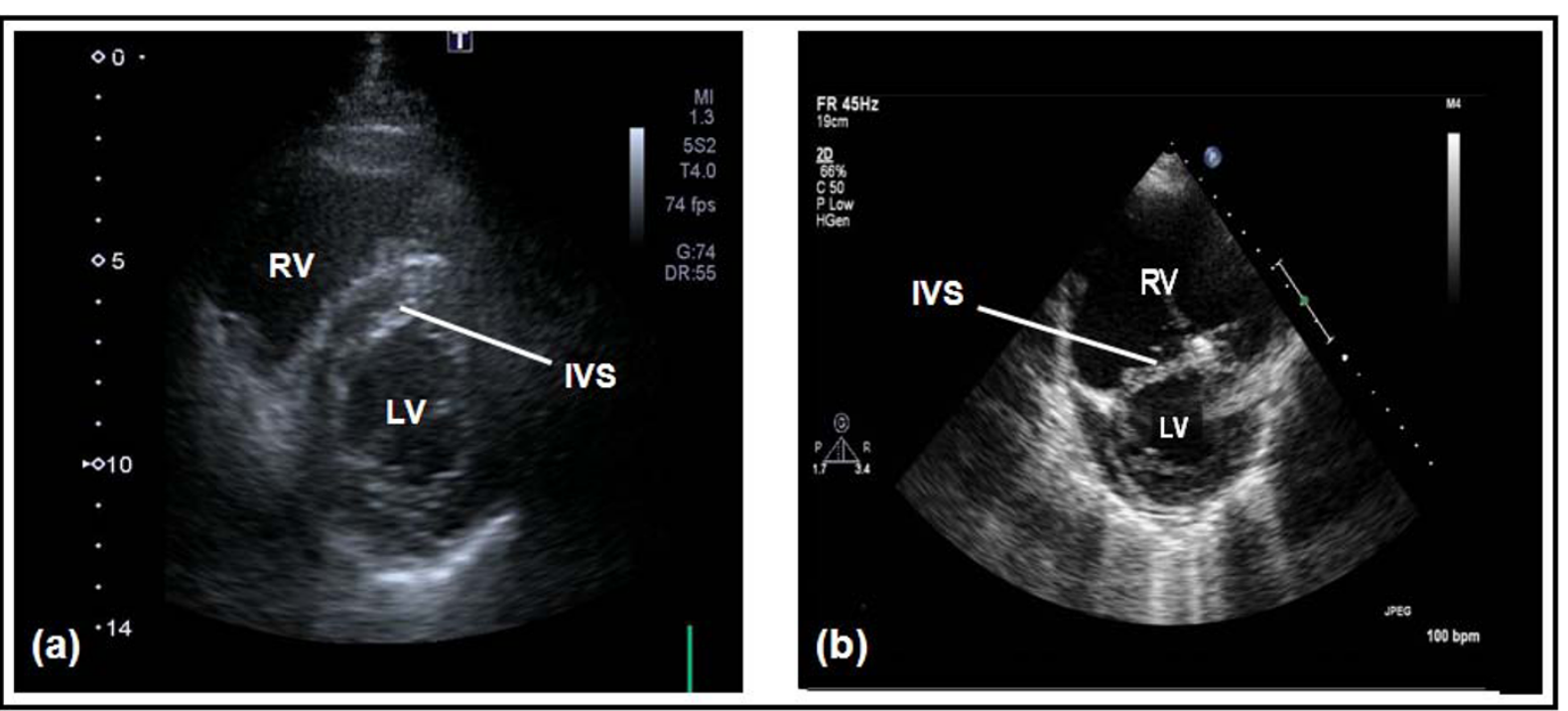

Figure 1 Short-axis view of a transthoracic echocardiogram in a normal subject (a) and a patient with an acutely dilated right ventricle (RV) in the setting of high pulmonary vascular resistance (b). The intraventricular septum (IVS) is D-shaped in (b), reflecting the acute RV pressure overload in this patient, and marked enlargement of the RV in (b) compared with (a). Courtesy of Dr Susanna Price, Royal Brompton Hospital, London, UK.

afterload. This may lead to acute distention (Figure 1) $[4,43]$, with a resulting increase in oxygen consumption and reduction in contractility [44]. The dilated RV, together with paradoxic intraventricular septal movement [45], lead to reduced LV filling [46], cardiac output (CO), and oxygen delivery [47]. The principle of ventricular interdependence is important in most settings: superficial myocardial fibers encircle both ventricles; thus they are contained within the same pericardial cavity (except maybe after cardiac surgery), as well as sharing a septum, effectively existing "in series" [48,49]. This explains the decrease in LV output seen during positive-pressure ventilation $[48,50,51]$ and why RV pressure and volume overload cause diastolic dysfunction of the LV [52]. Furthermore, because of the RV/LV interactions, the LV may markedly depend on atrial contraction for filling and may tolerate atrial fibrillation and vasodilating therapy particularly poorly $[49,53,54]$.

In addition, perfusion of the right coronary artery is usually dependent on a pressure gradient between the aorta and the right ventricle, which, in the setting of increased RV afterload and decreased coronary blood flow, may lead to RV ischemia [55], with further severe hemodynamic decompensation [56] (Figure 2). In acuteon-chronic RV-pressure overload, the already-hypertrophied RV tolerates much higher pressures before decompensation [57,58], although the ability of the RV to augment $\mathrm{CO}$ in chronic $\mathrm{PH}$ may be restricted by its relatively "fixed" afterload. In any setting, the most common cause of increased RV afterload is an increase in PVR (Table 2).
The gold standard for the diagnosis and management of PH and RV dysfunction in the ICU setting is considered by some to be through pulmonary artery catheterization (PAC), even though most of the information can be obtained noninvasively by echocardiography: the requirement for PAC in this population remains controversial. It must, however, be acknowledged that it provides the only direct continuous measurement of right-sided pressures and direct measurement of RV afterload, whereby, through measurement of cardiac output, pulmonary pressures and the pulmonary artery occlusion pressure (PAOP, the "wedge"), the PVR can be calculated (Figure 3). Overall outcomes are not improved when the PAC is used in general in critically ill patients; and complications do occur [59]: the use in general is therefore declining. However, no studies have been done in the "pulmonary vascular" subpopulation. Alternative invasive hemodynamic measurements, such as CVP, may be useful surrogates for volume status in RV failure, by using the diastolic component of the CVP. Importantly, when monitoring CVP in patients with significant tricuspid regurgitation (TR), the variable $\mathrm{V}$ wave may be misleading, as it is included in the mean CVP calculation on most automated machines, and if rising, indicates RV overdistention. In the setting of cardiac surgery, one study shows that PAC use has reduced from $100 \%$ to $9 \%$ from 1997 to 2001, thought to reflect increased use of transesophageal echocardiography (TEE) [60]. In the setting of cardiac surgery, PAC may remain indicated for patients with $\mathrm{PH}$ and low $\mathrm{CO}$ and those predicted to have a 


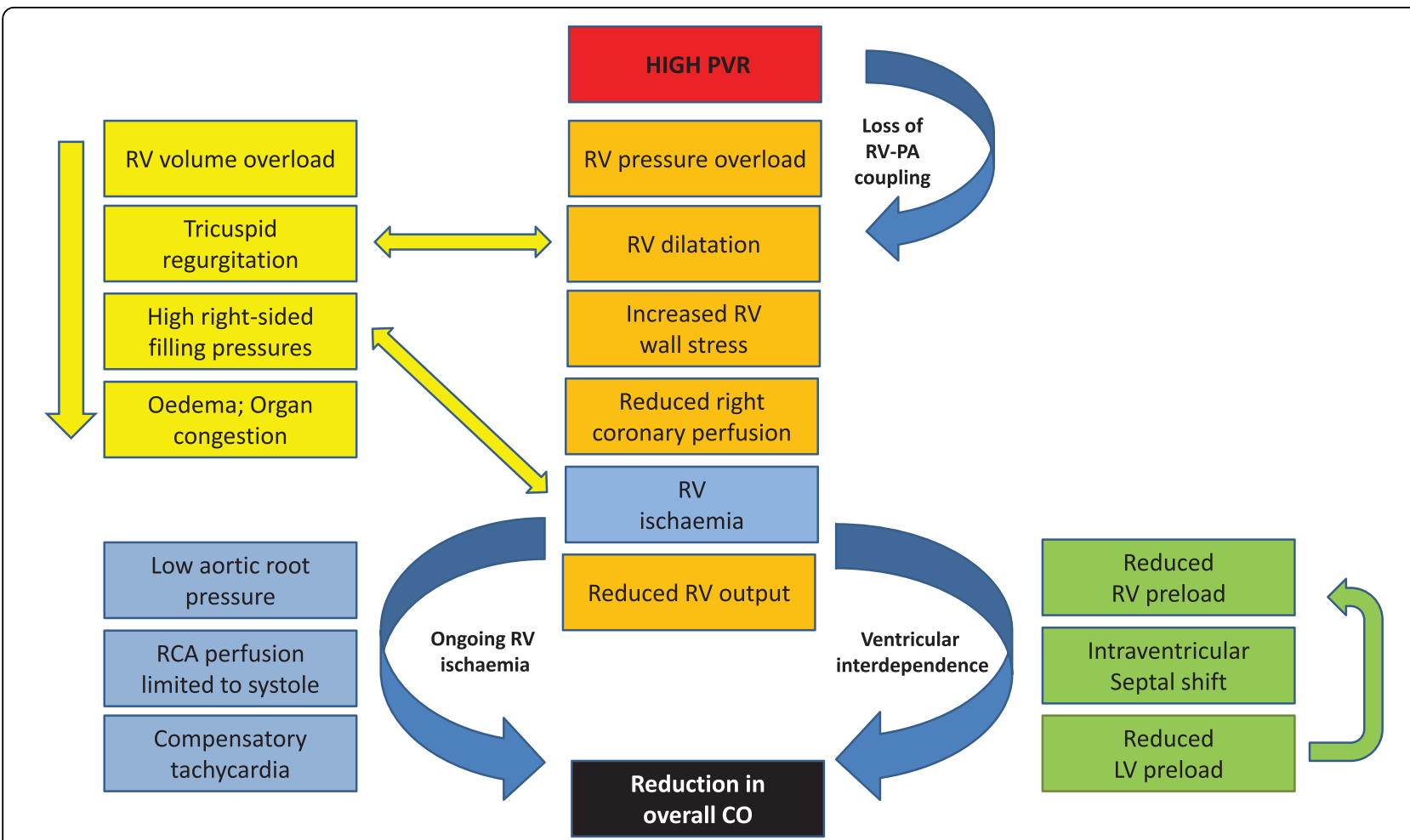

Figure 2 Pathophysiology of right ventricular failure in the setting of high PVR. CO, cardiac output; LV, left ventricle; MAP, mean arterial pressure; PVR, pulmonary vascular resistance; RV, right ventricle.

difficult postoperative course [60], when a Swan introducer sheath may be inserted preemptively, or inserted for continuous monitoring after a diagnosis of RV dysfunction made with echocardiography [61]. PAC is also a useful cardiac monitor with intraaortic balloon counterpulsation. Few data exist on PAC in other settings of pulmonary vascular dysfunction in the ICU, but one study suggests that PVR may be a poor indicator of pulmonary-circulation status in ventilated patients with ALI/ARDS [62]. The role of echocardiography, both transthoracic (TTE) and TEE, is increasingly recognized in assessing RV function in many ICU settings
[63-65] and provides essential information about RV geometry and function. PA pressures may be assessed by estimating the systolic-pressure gradient across the tricuspid valve by using the modified Bernoulli equation $[9,66,67]$, and although the correlation between invasive and sonographic measurement has been shown to be excellent in these studies, no studies have correlated PAC with echocardiographic measurements in the ICU population. In reality, a combination of invasive and noninvasive techniques is used. Biomarkers such as brain natriuretic peptide (BNP) are useful in monitoring chronic PAH [68], in risk-stratifying

Table 2 Local factors increasing pulmonary vascular tone

\begin{tabular}{ll}
\hline Factors increasing pulmonary vascular tone & Additional contributors to elevated PVR in ARDS \\
\hline High pulmonary arterial $\mathrm{pCO}_{2} /$ low pH & Vasoconstrictor: vasodilator imbalance \\
Low mixed venous $\mathrm{pO}_{2}$ & Excess ET-1 [361], TXA-1, PDE, 5HT [2] \\
High sympathetic tone; $\alpha$-adrenoceptor agonism & Reduced NO, prostanoids [20] \\
$\begin{array}{l}\text { Mechanical effects: } \\
\quad \text { High airway } \mathrm{P}_{\text {plati }} \text { gravity; increased flow (for example, one-lung ventilation) }\end{array}$ & Effects of endotoxin [22,362] \\
Relating to CPB: & Hypoxic vasoconstriction (80\% arteriolar) [22,364] \\
$\quad$ Preexisting PH; endothelial injury [17]; protamine [18] & Microthrombosis, macrothrombosis [62,365]
\end{tabular}

5-HT, serotonin; ARDS, acute respiratory distress syndrome; $\mathrm{CPB}$, cardiopulmonary bypass; $\mathrm{ET}-1$, endothelin-1; $\mathrm{NO}$, nitric oxide; $\mathrm{pCO}_{2}$, partial pressure of carbon dioxide; PDE, phosphodiesterase; $\mathrm{PO}_{2}$, partial pressure of oxygen; $\mathrm{P}_{\text {plat, }}$ plateau pressure; PVR, pulmonary vascular resistance; TXA-1, thromboxane A1. 


\section{$P V R=80 \times(m P A P-P A O P) / C O$}

Figure 3 Calculation of pulmonary vascular resistance. Normal range, $155-255$ dynes $/ \mathrm{sec} / \mathrm{cm}^{5}$. CO, cardiac output; mPAP, mean pulmonary artery pressure; $\mathrm{PAOP}$, pulmonary arterial occlusion pressure.

acute pulmonary embolism (see later) [69-71], and in identifying ARDS-related pulmonary vascular dysfunction [72], although their role is less clear in other ICU settings.

The diagnosis and management of acute pulmonary embolism (PE) warrants a specific mention, as it is a relatively common cause of acute RV failure in the ICU [73]. Available therapies include thrombolysis and embolectomy, reducing the clot burden and acute mortality [74,75], as well as reducing the longer-term risk of chronic thromboembolic PH [76]. Given that more than half of related deaths occur within an hour of the onset of symptoms [77], effective supportive treatment of shock is paramount. Patients presenting with acute PE are risk stratified according to the effects of elevated RV afterload: hypotensive patients and those with elevated cardiac biomarkers or echocardiographic indices of RV strain, or both, are deemed at increased risk, and thrombolysis is indicated [78].

The management of $\mathrm{PH}$ and $\mathrm{RV}$ dysfunction in the ICU is challenging. No agreed algorithms exist, although treatment should aim to prevent pulmonary hypertensive crises and acute cor pulmonale [79]. These comprise the spectrum of acute pulmonary vascular dysfunction and may result in cardiovascular collapse due to resulting biventricular failure. Management principles include the following: 1) optimization of RV preload, 2) optimization of RV systolic function, 3) reduction of afterload by reduction of increased PVR, and 4) maintenance of aortic root pressure to ensure sufficient right coronary artery filling pressure (Table 3$)$.

\section{Materials and methods}

Systematic review of ICU management of pulmonary vascular and RV dysfunction

We performed a systematic review of the literature over the period from 1980 to 2010, by using set search terms, and the electronic database of the US National Library of Medicine and National Institute of Health (PubMed). After initial identification, abstracts were reviewed for relevance, and appropriate studies were included in the review. Reference lists of relevant articles were hand-searched for further studies and reports. The search was limited to publications in English. Studies were deemed suitable for inclusion according to the criteria listed and where the patient population and study design was defined; and the outcomes were limited to those depending on the specific GRADE question (see Additional file 1). The breakdown of articles obtained by the systematic search is shown (Table 4). After identification, relevant studies were included and subjected to a GRADE analysis $[80,81]$ to see whether we could make specific management recommendations.

\section{Results and Discussion \\ ICU management of pulmonary vascular and RV dysfunction}

Management of $\mathrm{PH}$ with associated RV dysfunction in the ICU setting can be broken down into several treatment goals (Table 3). The first is to ensure adequate but not excessive RV filling or preload in the context of sufficient systemic blood pressure. The second goal is to maximize RV myocardial function, whether with inotropic support, rate or rhythm management, atrioventricular synchronization $[82,83]$, or by using mechanical devices. The third is to offload the right ventricle by reducing the PVR with pulmonary vasodilators as well as by ensuring adequate oxygenation, avoiding hypercapnia and acidosis, and by minimizing mechanical compression of pulmonary vessels (for example, due to excessive airway plateau pressure). The fourth is to maintain adequate aortic root pressure to allow sufficient right coronary arterial perfusion.

\section{Table 3 Management principles in pulmonary vascular dysfunction}

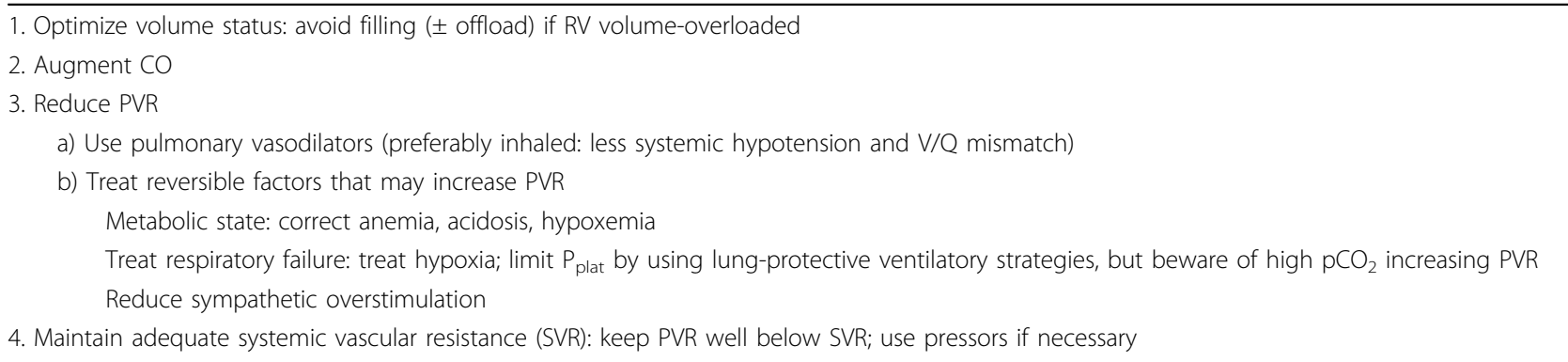


Table 4 Breakdown of clinical articles

\begin{tabular}{lll}
\hline $\begin{array}{l}\text { Subtype of treatment for } \\
\text { pulmonary vascular } \\
\text { dysfunction }\end{array}$ & $\begin{array}{l}\text { Number of } \\
\text { studies in initial } \\
\text { search }\end{array}$ & $\begin{array}{l}\text { Number of suitable } \\
\text { studies included in } \\
\text { review }\end{array}$ \\
\hline Volume therapy & 113 & 5 \\
Vasopressors & 388 & 28 \\
Sympathetic inotropes & 565 & 8 \\
Inodilators & 280 & 17 \\
Levosimendan & 172 & 12 \\
Pulmonary vasodilators & 586 & 121 \\
Mechanical devices & 47 & 19 \\
\hline
\end{tabular}

\section{Management of volume and use of vasopressors}

Systemic hypotension may relate to sepsis, overdiuresis, or progression of RV failure itself. Principles of volume management and vasopressor use are summarized.

\section{Volume management}

With a normal RV, RV ejection fraction is usually primarily dependent on RV preload [84]. In the setting of excessive myocardial distention (by fluids), wall tension increases according to the Frank-Starling mechanism, and muscle fiber length is increased, beyond a certain point at which ventricular function will fail. This situation may be precipitated sooner in the setting of $\mathrm{PH}$ and RV dysfunction, in which both hypo- and hypervolemia may reduce cardiac output $[78,85,86]$. In stable patients with $\mathrm{PAH}$, high plasma volumes are associated with worse outcomes [87], but very few clinical studies have been performed in pulmonary vascular dysfunction, and the use of fluid loading remains controversial. Some animal studies show that fluids increase the cardiac index [88]; others show that they worsen shock by inducing RV ischemia or decreasing LV filling or both as the result of ventricular diastolic interdependence (due to an increase in RV volume) [89-91].

In acute cor pulmonale after massive $\mathrm{PE}$, increased filling may be at least initially required $[4,92]$. In observational studies in sepsis, up to $40 \%$ of patients have evidence of RV failure [93], predominantly due to primary RV dysfunction [7]. These patients have a higher CVP at baseline [94] and are unable to augment stroke volume or perfusion pressure with fluid challenges alone, and so usually also require catecholamines $[93,94]$.

RV volume overload is a very important principle to recognize and treat promptly in RV failure. It may be identified by a rising $\mathrm{V}$ wave on the CVP trace, or by increased TR due to RV overdistention seen at echocardiography. In this situation of "backwards" heart failure, no further escalation of vasoactive agents is likely to be helpful (and may even be harmful), and management involves fluid removal (by using diuresis [95] or hemofiltration [96]) and avoidance of excessive RV afterload
[97]. Unmonitored fluid challenges are inadvisable in any setting of RV failure $[98,99]$.

\section{GRADE RECOMMENDATION 1}

Based on overall very-low-quality evidence (see Additional file 1), the following WEAK recommendation is made: Close monitoring of fluid status according to effects on RV function is recommended. Initial carefully monitored limited volume loading may be useful after acute PE, but may also worsen RV performance in some patients with pulmonary vascular dysfunction, and vasoactive agents may be required.

\section{Vasopressors}

An essential goal is to maintain systemic blood pressure above pulmonary arterial pressures, thereby preserving right coronary blood flow: unlike left coronary artery perfusion, which occurs only during diastole (as aortic pressure exceeds LV pressure only during this period), perfusion of the right coronary artery usually occurs throughout the cardiac cycle, dominating in systole. It is understood that, as PVR approaches SVR, coronary perfusion will decrease, and if PVR exceeds SVR, coronary filling will occur only in diastole. By augmenting aortic root pressure by using vasopressors in the setting of increased RV afterload, RV ischemia can therefore be reversed [55]. Vasopressors will, however, inevitably have direct effects on the pulmonary circulation as well as myocardial effects (Table 5).

Sympathomimetic pressors These include the catecholaminergic pressor, norepinephrine, and the noncatecholaminergic pressor phenylephrine. Their complex effects on the pulmonary circulation depend on the dose-related relative $\alpha$ - and $\beta$-adrenoreceptor stimulation as well as the degree and nature of RV dysfunction $[99,100]$. All may potentially lead to tachydysrhythmias, diastolic dysfunction, myocardial ischemia, hyperlactatemia, and hypercoagulability [101].

Norepinephrine Norepinephrine (NE) exerts its systemic vasopressor effects through $\alpha-1$ agonism [102]. Activation of these receptors also causes pulmonary vasoconstriction [102,103], although the potential adverse effects on PVR are likely to occur only at high doses. Most evidence supporting this comes from animal studies in models of pulmonary vascular dysfunction, with NE at doses less than $0.5 \mu \mathrm{g} / \mathrm{kg} / \mathrm{min}$ not increasing PVR [44]. In persistent $\mathrm{PH}$ of the newborn, low-dose NE $(0.5 \mu \mathrm{g} / \mathrm{kg} / \mathrm{min})$ reduces the PVR/SVR ratio [104]. In adults with septic shock, higher doses of NE increase PVR/SVR, although without worsening RV performance [105]. In patients with sepsis, $\mathrm{PH}$, and associated RV dysfunction, NE increases SVR and improves the RV oxygen supply/demand ratio, although it does not increase RVEF and does increase PVR [106]. Importantly, NE is positively inotropic through $\beta-1$ 
Table 5 Pulmonary vascular properties of vasoactive agents

\begin{tabular}{|c|c|c|c|c|c|c|}
\hline & $\mathrm{Cl}$ & PVR & SVR & PVR/SVR & Tachycardia & Renal $^{\mathrm{a}} /$ metabolic \\
\hline Vasopressors & & & & Dose related & & \\
\hline NE & + & + & ++ & $+/-$ & + & Lactic acidosis \\
\hline PHE & - & ++ & + & + & - & - \\
\hline Low-dose AVP & $+/-$ & $+/-$ & ++ & - & - & Diuresis ++ \\
\hline \multicolumn{7}{|l|}{ Inotropes } \\
\hline Dobutamine & ++ & - & - & - & + & \\
\hline \multicolumn{7}{|l|}{$<5 \mu \mathrm{g} / \mathrm{kg} / \mathrm{min}$} \\
\hline Dopamine & + & $+/-$ & + & + & ++ & Natriuresis \\
\hline Epinephrine & ++ & - & ++ & - & ++ & Lactic acidosis \\
\hline \multicolumn{7}{|l|}{ Inodilators } \\
\hline PDE IIIS & ++ & - & - & - & $+/-$ & - \\
\hline Levosimendan & ++ & - & - & - & - & - \\
\hline
\end{tabular}

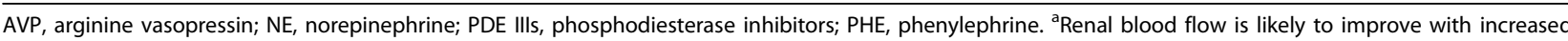
cardiac output and systemic blood pressure with all agents.

receptor agonism, thus improving RV/pulmonary arterial coupling, $\mathrm{CO}$, and RV performance in studies of acute RV dysfunction due to $\mathrm{PH}[44,89,107-109]$, illustrated in a case report of acute PH after MVR surgery [110]. In patients with chronic $\mathrm{PH}, \mathrm{NE}$ reduces the PVR/SVR ratio, although it may not improve CI [100], which may relate to the "fixed" elevation in PVR [99].

Phenylephrine Phenylephrine (PHE) is a direct $\alpha$-agonist. Its use improves right coronary perfusion in RV failure [55] without causing tachycardia, although this benefit may be offset by worsening RV function due to increased PVR [100,108,111].

\section{GRADE RECOMMENDATION 2}

Based on mostly low-quality evidence (see Additional file 1), the following WEAK recommendation is made: $\mathrm{NE}$ may be an effective systemic pressor in patients with acute RV dysfunction and RV failure, as it improves RV function both by improving SVR and by increasing CO, despite potential increases in PVR at higher doses.

\section{Nonsympathomimetic pressors: Vasopressin}

Arginine vasopressin (AVP) causes systemic vasoconstriction via the vasopressinergic (V1) receptor. Experimental studies have revealed vasodilating properties at low doses that include pulmonary vasodilatation [112] through an NO-dependent mechanism via $\mathrm{V}_{1}$ receptors $[113,114]$. This property manifests clinically as a reduction in PVR and PVR/SVR ratio $[105,115,116]$. AVP has also been used as a rescue therapy in patients during PH crises [117-119], in which untreated equalization of systemic and pulmonary pressures may be rapidly fatal. At low doses (0.03-0.067 U/min), it has been used safely in sepsis [105,120-124], as well as in patients with acute
$\mathrm{PH}$ and RV failure with hypotension after cardiac surgery $[115,116,125,126]$ and hypotension associated with chronic PH in several settings $[117,118,127,128]$.

AVP leads to a diuretic effect in vasodilatory shock [129], reduces the heart rate [105,121,130-132], and induces fewer tachyarrhythmias in comparison to $\mathrm{NE}$ $[105,131]$. However, bradycardia [133] may be encountered at high clinical doses $[134,135]$. AVP may cause dose-related adverse myocardial effects at infusion rates exceeding $0.4 \mathrm{U} / \mathrm{min}[134,135]$, or even above $0.08 \mathrm{U} /$ min in cardiogenic shock [136], which probably relate to direct myocardial effects, including coronary vasoconstriction [132,137-139].

\section{GRADE RECOMMENDATION 3}

Based on mostly low-quality evidence (see Additional file 1), the following WEAK recommendation is made: In patients with vasodilatory shock and pulmonary vascular dysfunction, low-dose AVP may be useful in difficult cases that are resistant to usual treatments, including norepinephrine.

\section{Inotropic augmentation of RV myocardial function}

The next major goal is to improve RV myocardial function by using inotropes. The use of mechanical support is discussed later. For sympathomimetic agents, desirable cardiac $\beta_{1}$ effects at lower doses maybe offset by chronotropic effects precipitating tachyarrhythmias [140], as well as worsening pulmonary vasoconstriction at higher doses [102] through $\alpha$-agonism. Systemic hypotension may result from these agents and with phosphodiesterase inhibitors, which may necessitate co-administration of vasopressors. 


\section{Inotropes}

\section{Sympathomimetic inotropes}

Few clinical studies of these agents have been done in patients with $\mathrm{PH}$ and $\mathrm{RV}$ dysfunction. Dopamine increases $\mathrm{CO}$, although it may cause a mild tachycardia in patients with $\mathrm{PH}$ [141] and increase the PVR/SVR ratio [142]. Dopamine also tends to increase the heart rate and to have less-favorable hemodynamic effects in patients with cardiomyopathy than dobutamine [143], although it does not increase PVR at doses up to $10 \mu \mathrm{g} /$ $\mathrm{kg} / \mathrm{min}$ in animals with pulmonary vascular dysfunction [144]. In patients with septic shock, PH, and RV dysfunction, dopamine improves CI without an increase in PVR [145]. In the recent large randomized controlled study comparing dopamine with norepinephrine in patients with septic shock, dopamine increased arrhythmic events and, in patients with cardiogenic shock, increased the risk of death [146]. In patients with primary RV dysfunction (without $\mathrm{PH}$ ) due to septic shock, epinephrine improves RV contractility despite an 11\% increase in mPAP [14]. In animal studies, epinephrine reduces the PVR/SVR more than does dopamine [147]. Isoproterenol has been used in RV failure primarily as a chronotrope after cardiac transplantation [148], although it may induce arrhythmias [149].

Dobutamine At clinical doses up to $5 \mu \mathrm{g} / \mathrm{kg} / \mathrm{min}$ in heart failure, dobutamine increases myocardial contractility, reduces PVR and SVR, and induces less tachycardia than does dopamine [143]. It improves RV performance in patients with $\mathrm{PH}$ at liver transplantation [150], after RV infarction [151], and is used in PAH exacerbations [152]. It is synergistic with $\mathrm{NO}$ in patients with $\mathrm{PH}$ [153]. Experimentally, dobutamine has favorable pulmonary vascular effects at lower doses [44,154], although it leads to increased PVR, tachycardia, and systemic hypotension at doses exceeding $10 \mu \mathrm{g} / \mathrm{kg} / \mathrm{min}$ [155]. Given the adverse effects of systemic hypotension in these patients, it is important to anticipate and treat it with vasopressors when using dobutamine.

\section{Inodilators}

An inodilator increases myocardial contractility while simultaneously causing systemic and pulmonary vasodilatation. Inodilators include the phosphodiesterase (PDE) III inhibitors and levosimendan.

PDE3 inhibitors Several types of PDE are recognized: PDEIII usually deactivates intracellular cyclic adenosine monophosphate (cAMP), and PDE3 inhibitors therefore increase cAMP and augment myocardial contractility while dilating the vasculature [156-158]. The selective PDEIII inhibitors include enoximone, milrinone, and amrinone. They are most suited to shortterm use because of tachyphylaxis [159], and mild tachycardia is common. Milrinone is most frequently used and has been shown to reduce pulmonary pressures and augment RV function in many studies in patients with pulmonary vascular dysfunction [160-164]. Enoximone improves RV function in pulmonary vascular dysfunction after cardiac surgery $[165,166]$ and in patients with decompensated chronic obstructive pulmonary disease (COPD) [167]. Enoximone leads to fewer postoperative myocardial infarctions than does dobutamine $[168,169]$, which may relate to the resulting improved gas exchange when compared with dobutamine and GTN [170]. Concerns regarding platelet aggregation with amrinone [171] do not appear to arise with enoximone [172] or milrinone after cardiac surgery $[173,174]$. As with dobutamine, resulting reversible systemic hypotension means that coadministration with pressors is often necessary. Agents such as norepinephrine, phenylephrine or vasopressin are used, with the latter reducing PVR/SVR more than norepinephrine [115]. PDEIII inhibitors may also improve RV function in chronic $\mathrm{PH}$ [175].

Nebulized milrinone is increasingly used to manage $\mathrm{PH}$ crises in several settings [176-179]. Through pulmonary selectivity, it results in less systemic hypotension and less $\mathrm{V} / \mathrm{Q}$ mismatch compared with intravenous use in patients with $\mathrm{PH}$ after mitral valve replacement surgery $[177,178]$. The combination of milrinone-AVP reduces PVR/SVR and may be preferable to milrinoneNE in RV dysfunction [115].

Levosimendan Levosimendan sensitizes troponin- $C$ to calcium and selectively inhibits PDE III, improving diastolic function and myocardial contractility without increasing oxygen consumption [180-183]. It also acts as a vasodilator through calcium desensitization, potassium channel opening, and PDEIII inhibition [184]. Levosimendan leads to a rapid improvement in hemodynamics, including reduction in PVR in patients with decompensated heart failure [185], with significant benefit on RV efficiency [182], with effects lasting several days [186]. Levosimendan improves RV-PA coupling in experimental acute RV failure [187-189] more than dobutamine [188]. These effects have been shown clinically with improvements in RV function and reduction in PVR in ischemic RV failure [190-194], ARDS [195], and after mitral valve replacement surgery [196,197]. In chronic $\mathrm{PH}$, repetitive doses reduce mPAP and PVR from baseline and improve $\mathrm{SvO}_{2}$ [198].

\section{GRADE RECOMMENDATION 4}

Based on low-moderate-quality evidence (see Additional file 1), a WEAK recommendation can be made that lowdose dobutamine (up to $10 \mu \mathrm{g} / \mathrm{kg} / \mathrm{min}$ ) improves $\mathrm{RV}$ function and may be useful in patients with pulmonary vascular dysfunction, although it may reduce SVR. Dopamine may increase tachyarrhythmias and is not recommended in the setting of cardiogenic shock 
(STRONG recommendation based on high-quality evidence level).

\section{GRADE RECOMMENDATION 5}

Based on mostly moderate-quality evidence (see Additional file 1), a STRONG recommendation can be made that PDE III inhibitors improve RV performance and reduce PVR in patients with acute pulmonary vascular dysfunction, although systemic hypotension is common, usually requiring coadmininstration of pressors. Based on low-quality evidence (see Additional file 1), a WEAK recommendation can be made that inhaled milrinone may be useful to minimize systemic hypotension and V/Q mismatch in pulmonary vascular dysfunction.

\section{GRADE RECOMMENDATION 6}

Based on mostly low-quality evidence (see Additional file 1), a WEAK recommendation can be made that levosimendan may be considered for short-term improvements in RV performance in patients with biventricular heart failure.

\section{Reduction of right ventricular afterload}

Physiologic coupling between the RV and the pulmonary circulation is a vital form of autoregulation of pulmonary circulatory flow (Figure 2). The RV is even less tolerant of acute changes in afterload than the LV, presumably because of the lower myocardial muscle mass [199]. In sepsis, a reduction in PVR will increase the RV ejection fraction at no additional cost to cardiac output [47], but at levels beyond moderate PH, LV filling may be reduced, and ultimately cardiac output will decrease [199]. Measures to reduce RV afterload may be nonpharmacologic (Table 3) or pharmacologic (Table 6).

\section{Pulmonary vasodilator therapy}

Specific pulmonary vasodilators may be useful both to reduce RV afterload and to manipulate hypoxic vasoconstriction in patients with severe hypoxia. Agents are classically subdivided according to their action on the cyclic GMP, prostacyclin, or endothelin pathways [200]. In the nonacute setting, these agents also target remodeling of "resistance" pulmonary vessels and have

\section{Table 6 Agents used to reduce PVR in the ICU setting}

\begin{tabular}{|c|c|c|c|}
\hline Drug & Dose & $\begin{array}{l}\text { Half-life } \\
\text { (duration } \\
\text { of action) }\end{array}$ & Potential adverse effects \\
\hline \multicolumn{4}{|l|}{ Intravenous } \\
\hline $\begin{array}{l}\text { Prostacyclin (Epoprostenol, } \\
\text { Flolan) }\end{array}$ & $\begin{array}{l}\text { Start at } 1 \mathrm{ng} / \mathrm{kg} / \mathrm{min} \text {; titrate upward } \\
\text { in } 2-\mathrm{ng} / \mathrm{kg} / \mathrm{min} \text { increments according } \\
\text { to effect }\end{array}$ & $\begin{array}{l}3-5 \text { minutes } \\
\text { (10 minutes) }\end{array}$ & $\begin{array}{l}\text { Systemic hypotension, worsening oxygenation (increased } \\
\text { V/Q mismatch), antiplatelet effect, headache, flushing, jaw } \\
\text { pain, nausea, diarrhea }\end{array}$ \\
\hline lloprost & $1-5 \mathrm{ng} / \mathrm{kg} / \mathrm{min}$ & 30 minutes & Similar to Flolan; also syncope (5\%) \\
\hline $\begin{array}{l}\text { Sildenafil [325] (NB off- } \\
\text { license use in } \\
\text { hemodynamically unstable } \\
\text { patients) }\end{array}$ & $\begin{array}{l}\text { Low dose, } 0.05 \mathrm{mg} / \mathrm{kg} \text {; high dose, } \\
0.43 \mathrm{mg} / \mathrm{kg} \text { ) (comes as } 0.8 \mathrm{mg} / \mathrm{ml} \text { ) }\end{array}$ & 3-5 hours & $\begin{array}{l}\text { Hypotension: caution if fluid depleted, severe LV-outflow } \\
\text { obstruction, autonomic dysfunction. Hypoxemia due to V/Q } \\
\text { mismatch. Common: headache, flushing, diarrhea, epistaxis, } \\
\text { tremor. Rare but important: anterior ischemic optic } \\
\text { neuropathy }\end{array}$ \\
\hline Milrinone & $\begin{array}{l}50 \mu \mathrm{g} / \mathrm{kg} \text { over } 10 \text { minutes followed } \\
\text { by } 0.375-0.75 \mu \mathrm{g} / \mathrm{kg} / \mathrm{min} \text { infusion }\end{array}$ & $1-2$ hours & Tachyarrhythmias, hypotension \\
\hline Adenosine & $\begin{array}{l}50-350 \mu \mathrm{mg} / \mathrm{kg} / \mathrm{min} \text {, titrate up in } \\
50 \mu \mathrm{gg} / \mathrm{kg} / \mathrm{min} \text { increments }\end{array}$ & $\begin{array}{l}5-10 \\
\text { seconds } \\
\text { (2 minutes) }\end{array}$ & Bradycardia, bronchospasm, chest pain \\
\hline \multicolumn{4}{|l|}{$\begin{array}{l}\text { Inhaled (preferred; Note } \\
\text { variable absorption likely) }\end{array}$} \\
\hline $\begin{array}{l}\text { Prostacyclin (Epoprostenol, } \\
\text { Flolan) }[286,303]\end{array}$ & $\begin{array}{l}0.2-0.3 \mathrm{ml} / \mathrm{min} \text { of } 10-20 \mu \mathrm{gg} / \mathrm{ml} \\
\text { nebulized into inspiratory } \mathrm{limb} \text { of } \\
\text { ventilator circuit ( } 30-40 \mathrm{ng} / \mathrm{kg} / \mathrm{min} \text { ) }\end{array}$ & 3-5 minutes & $\begin{array}{l}\text { As above but less hypotension and improved oxygenation } \\
\text { compared with intravenous use }\end{array}$ \\
\hline lloprost [275] & $\begin{array}{l}2.5-5 \mu \mathrm{g} 6-9 \text { times } / \text { day, } 1 \mathrm{mg} / \mathrm{ml} \\
\text { milrinone into the ventilator circuit } \\
\text { at } 0.2-0.3 \mathrm{ml} / \mathrm{min} \text { for } 10-20 \text { minutes }\end{array}$ & 30 minutes & As above and bronchospasm \\
\hline Milrinone $[176,178,179]$ & 5-80 ppm continuously & $1-2$ hours & Less systemic hypotension than with IV milrinone \\
\hline NO & & $\begin{array}{l}15-30 \\
\text { seconds } \\
\text { (5 minutes) }\end{array}$ & Methemoglobinemia; withdrawal PH \\
\hline \multicolumn{4}{|l|}{ ORAL (rarely in ICU) } \\
\hline Bosentan & $62.5-125 \mathrm{mg}$ b.d. & 5 hours & Liver-function test abnormalities; drug interactions; edema \\
\hline Sildenafil & $0.25-0.75 \mathrm{mg} / \mathrm{kg} 4$ hrly & 3-4 hours & $\begin{array}{l}\text { As above; less hypotension and hypoxemia in stable } \\
\text { patients }\end{array}$ \\
\hline
\end{tabular}


revolutionized the care of patients with PAH [201]. Importantly, however, the management with pulmonary vasodilators in chronic $\mathrm{PH}$ patients differs in several ways from that with acute pulmonary vascular dysfunction, notably in terms of rapid changes in RV volume status, and potential adverse hemodynamic effects of nonselective pulmonary vasodilators in unstable patients.

Pulmonary vasodilators should be used after optimization of RV perfusion and CO. Systemic administration of pulmonary vasodilators may reduce systemic blood pressure [202], potentially reducing RV preload and worsening RV ischemia [86]. Exclusion of a fixed elevated pulmonary venous pressure is important, as increased transpulmonary flow may precipitate pulmonary edema [203,204]. Furthermore, nonselective actions of vasodilators may result in worsening ventilation/ perfusion (V/Q) matching [205]. This risk is reduced with the use of inhaled pulmonary vasodilators, with which the agent will reach vessels in only ventilated lung units [206].

\section{Adenosine}

Adenosine increases intracellular cAMP via $\mathrm{A}_{2}$ receptor agonism [207], and when administered intravenously, acts as a potent selective pulmonary vasodilator because of its rapid endothelial metabolism [208]. It has been used as a therapy for adult $\mathrm{PH}$ in some settings, including after cardiac surgery [209], but may elevate LV enddiastolic pressure [210] and cause bradycardia and bronchospasm [211]. It is currently therefore recommended as an alternative to $\mathrm{NO}$ and prostacyclin in dynamic vasoreactivity studies rather than as treatment for PH [201].

\section{Inhaled nitric oxide}

Inhaled nitric oxide (NO) is a potent pulmonary vasodilator with a short half-life due to rapid inactivation by hemoglobin. This minimizes systemic vasodilatation, although it necessitates continuous delivery into the ventilator circuit [206]. NO selectively reduces PVR and improves $\mathrm{CO}$ in PAH [212], secondary PH [205,213,214], acute PE [215,216], ischemic RV dysfunction $[217,218]$, and postsurgical PH [202,219-234]. NO also improves oxygenation [235], RVEF, and reduces vasopressor requirements in $\mathrm{PH}$ after cardiac surgery [236], especially in patients with higher baseline PVR [237], with no augmented effect seen at doses above 10 ppm in these patients [238]. Use of NO (or inhaled $\mathrm{PGI}_{2}$ ) after mitral valve replacement surgery results in easier weaning from cardiopulmonary bypass and shorter ICU stays $[239,240]$.

$\mathrm{NO}$ has been shown to reduce PVR and improve $\mathrm{CO}$ in several studies in patients with acute RV failure due to ARDS [79,241-246] and to improve oxygenation at lower doses than the RV effects [247]. Administration of NO does need to be continuous for PVR reduction, and a potential exists for worsening oxygenation at excessive doses [248]. The reduction in RV afterload, however, does not correlate with clinical-outcome benefits [249-251]. Similarly, despite short-term improvements in oxygenation in ARDS [252], no studies show a survival benefit [249,250,253-257].

NO provides synergistic pulmonary vasodilatation with intravenous prostacyclin [258], inhaled iloprost [259], and oral sildenafil $[260,261]$. Limitations include accumulation of toxic metabolites, although this is not usually a clinically significant problem [206]. Rebound $\mathrm{PH}$ with RV dysfunction may occur after weaning from NO [262-264], which may be reduced with PDE5 inhibitors [265-270].

\section{Prostanoids}

Prostanoids include prostaglandin- $\mathrm{I}_{2}$ (prostacyclin, $\mathrm{PGI}_{2}$ ) and its analogues, (iloprost) and prostaglandin- $E_{1}$ (alprostadil, $\mathrm{PGE}_{1}$ ). An important difference between their formulations is their resulting half-life (Table 6). Prostacyclin is a potent systemic and pulmonary vasodilator, with antiplatelet [271] and antiproliferative effects [272]. In PAH, these agents reduce PVR, increase CO, and improve clinical outcomes [273-279], and are used in patients with NYHA III-IV symptoms [201].

The use of prostanoids is most commonly described in ICU after cardiac surgery or transplantation. Intravenous prostacyclin [18,280], $\mathrm{PGE}_{1}$ [281-285], inhaled prostacyclin [223,286-290], and iloprost [291-297] all reduce PVR and improve RV performance in these settings, with inhaled agents being most selective. Intravenous $\mathrm{PGE}_{1}$ may cause marked desaturation in patients with lung disease [205]. Inhaled prostacyclin has shortterm equivalence to NO [226], and inhaled iloprost has been shown to be even more effective than NO at acutely reducing PVR and augmenting $\mathrm{CO}$ in $\mathrm{PH}$ after CPB [298] and in PAH [277]. Inhaled $\mathrm{PGI}_{2}$ also acutely improves pulmonary hemodynamics after acute massive $\mathrm{PE}$ [299]. Although $\mathrm{PGI}_{2}$ impairs platelet aggregation, clinical bleeding was not increased in one study [300]. The potential anticoagulant effect should be remembered, however, especially in patients after surgery and receiving concomitant heparin.

In ARDS, intravenous prostacyclin reduces PVR and improves RV function, although it may increase intrapulmonary shunt [301]. Inhaled prostacyclin [302-305] and inhaled $\mathrm{PGE}_{1}$ [306] improve oxygenation and reduce PVR in ARDS, with minimal effects on SVR. NO and intravenous $\mathrm{PGI}_{2}$ have been combined in ARDS with effective reduction of PVR without adverse effects [307].

\section{PDE5 inhibitors}

PDE5 inhibitors, including sildenafil and vardenafil, increase downstream cGMP signaling, potentiating the beneficial effects of NO (Figure 4). PDE5 inhibitors 


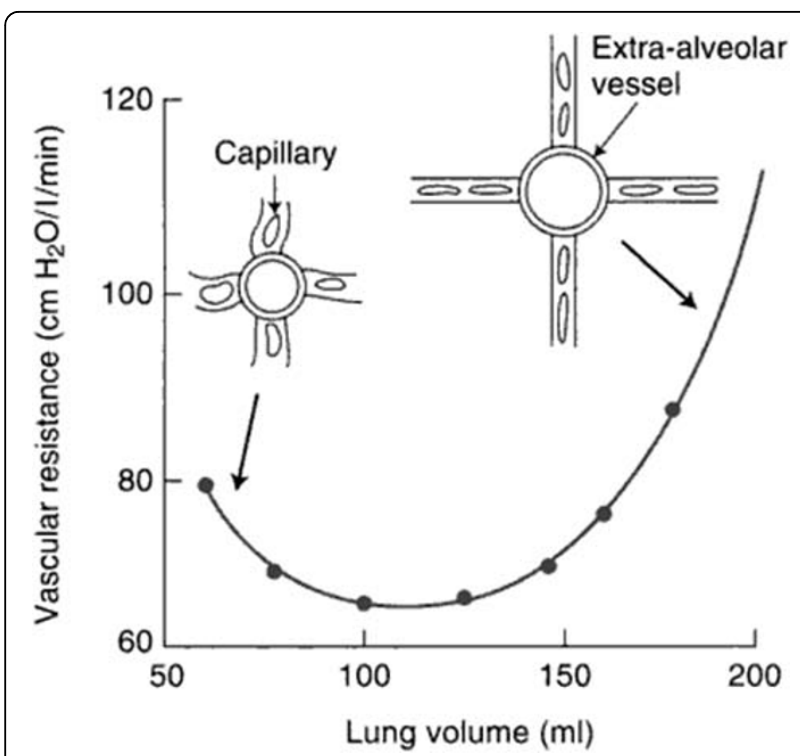

Figure 4 Increased PVR at extremes of lung volumes. This figure represents measurements made in an animal-lobe preparation in which the transmural pressure of the capillaries is held constant. It illustrates that at low lung volumes (as may occur with atelectasis), extraalveolar vessels become narrow, and smooth muscle and elastic fibers in these collapsed vessels increase PVR. At high lung volumes, as alveolar volumes are increased and walls are thinned, capillaries are stretched, reducing their caliber and also increasing PVR. (Adapted from John West's Essential Physiology, $10^{\text {th }}$ edition, Philadelphia: Lippincott \& Williams, with permission).

acutely reduce PVR [308,309], and increase CO and reduce PAOP more than does NO [310]. These agents improve clinical end-points in PAH [311], where endothelial NO is reduced [312] and PDE5 expression is upregulated [313,314]. PDE5 inhibitor may also exert milrinone-like effects through PDEIII inhibition, augmenting RV function [310,311,315]. Despite their relative pulmonary selectivity and rapid onset, however, adverse effects may include reduced SVR with potential effects on RV performance [316]. Oral sildenafil has been used to reduce PVR effectively in well-selected patients with $\mathrm{PH}$ after cardiac surgery without reducing the SVR [269,317-319]. Even a single dose may facilitate weaning from NO [266], also without reducing SVR [266-269]. Sildenafil may also improve myocardial perfusion and reduce platelet activation [320] as well as endothelial dysfunction after CPB [321]. Oral sildenafil has been effective in patients with $\mathrm{PH}$ due to left ventricular systolic dysfunction, reducing PVR and increasing CO, although reducing the SVR [260]. Sildenafil has also been used in selected patients with PH due to selected cases of chronic respiratory disease without worsening oxygenation or SVR [322,323]. A single dose of $50 \mathrm{mg}$ nasogastric sildenafil has been studied in a small cohort of consecutive ARDS patients, lowering MAP, and worsening oxygenation due to increased V/Q mismatch, although RV performance did improve [324]. Intravenous sildenafil has been shown to reduce SVR and PVR in end-stage congestive heart failure patients [325], although it is not available commercially, and its use is not licensed in unstable patients (Table 6).

\section{GRADE RECOMMENDATION 7}

Based on mostly moderate-quality evidence (see Additional file 1), the following STRONG recommendation is made: pulmonary vasodilators reduce PVR, improve $\mathrm{CO}$ and oxygenation, and may be useful when $\mathrm{PH}$ and RV dysfunction are present, notably after cardiac surgery.

Based on mostly moderate-quality evidence (see Additional file 1), the ICU side-effect profile of intravenous pulmonary vasodilators may be less favorable than that of inhaled agents. The following STRONG recommendation is therefore made: Consideration should be given to the use of inhaled rather than systemic agents when systemic hypotension is likely, and concomitant vasopressor use should be anticipated.

Based on mostly high-quality evidence (see Additional file 1), the following STRONG recommendation is made: give consideration for the use of $\mathrm{NO}$ as a shortterm therapy to improve oxygenation indices but not outcome in patients with ARDS. Based on low-quality evidence (see Additional file 1), a WEAK recommendation is made that pulmonary vasodilators may also be useful treat $\mathrm{PH}$ associated with $\mathrm{RV}$ dysfunction in ARDS.

Based on mostly low-quality evidence (see Additional file 1), the following WEAK recommendation is made: Oral sildenafil may reduce PVR and facilitate weaning from NO after cardiac surgery in selected patients with $\mathrm{PH}$, without adverse effects on systemic blood pressure in well-selected patients.

\section{Nonpharmacologic Management}

This encompasses RV "protective" strategies to avoid factors (Table 3) that may further increase PVR. Mechanical devices are also increasingly used to give a failing RV a bridge to recovery or transplantation.

\section{Ventilatory strategies}

Important variables that may reduce pulmonary blood flow during ventilation include hypoxia, hypercapnia, and compression of the pulmonary vasculature at the extremes of lung volumes (Figure 4). Acute hypoxia leading to hypoxic pulmonary vasoconstriction is well described [326] and may be augmented by many factors, including acidosis [327]. Acute hypercapnia also leads to pulmonary vasoconstriction [328,329], although this may be attenuated with NO [330], and, when associated with 
high PEEP, leads to RV dilatation and reduced cardiac output in severe ARDS [328,329]. A reduction in pulmonary blood flow occurs both at low volumes, such as in areas of atelectasis, and at high lung volumes, such as with increased airway plateau pressure $\left(\mathrm{P}_{\text {plat }}\right)$ : Increased RV afterload, reduced venous return, and acute RV dysfunction may result [331]. Both atelectasis and ventilation at high lung volumes should therefore be avoided in patients with RV dysfunction.

Before the era of protective ventilatory strategies in ARDS, the incidence of acute RV failure was $60 \%$ [332] and has since decreased to $10 \%$ to $25 \%$ [24]. This is thought to reflect the change in ventilatory practice: lower $\mathrm{P}_{\text {plat }}$ reduces the incidence of RV failure [333]. Prone ventilation may also reduce $\mathrm{P}_{\text {plat }}$ and $\mathrm{pCO}_{2}$ sufficiently to improve acute RV failure [334]. In ARDS, transition to high-frequency oscillation leads to an increase in CVP and a minor decrease in cardiac output due to preload reduction [335], and RV function may decrease during recruitment maneuvers [336]. In children after Fontan procedures, the hemodynamic effects of negative-pressure ventilation (NPV) are nicely illustrated by measuring pulmonary blood flow: after a switch from conventional intermittent positive pressure ventilation (IPPV) to NPV by using cuirass ventilation, pulmonary blood flow, stroke volume, and cardiac output increased up to $50 \%$, and decreased to baseline when IPPV was reinstituted [337,338].

\section{Mechanical support}

Mechanical support for the RV may be appropriate in reversible settings or as a bridge to definitive treatment. RV-assist devices (RVADs) may be used in primary RV dysfunction [339] and have been used with coexisting PH $[340,341]$. There is, however, concern that pulsatile devices may cause pulmonary microcirculatory damage in $\mathrm{PH}[342,343]$. A pumpless "lung assist" device has been used in patients bridging to transplant [344]. Extracorporeal membrane oxygenation (ECMO) has been used in severe PH [345-348], as a bridge to transplant $[349,350]$, and after endarterectomy [351] or massive PE [352-355]. Intraaortic balloon counterpulsation (IABP) has been used for RV failure after CPB [356] and transplantation [357], thought to improve $\mathrm{CO}$ by augmenting left coronary flow rather than by direct RV effects [358]. Atrial septostomy creates a right-to-left shunt that improves left atrial filling and LV function while reducing RV end-diastolic pressure and improving RV contractility. It is sometimes used as a bridge to transplantation in severe PAH [359], although not in patients with very severe RV failure [360].

\section{GRADE RECOMMENDATION 8}

Based on mostly very-low-quality evidence, the following WEAK recommendation is made: Mechanical therapies including ECMO and IABP may have a role as rescue therapies in reversible pulmonary vascular dysfunction or while awaiting definitive treatment.

\section{Conclusions}

Pulmonary vascular and right ventricular dysfunction may complicate many ICU illnesses: the diagnosis may be difficult, and the acute management, challenging. Their presence is associated with a worse outcome. This review highlights that some recommendations can be made, despite limitations of the GRADE analysis. However, we do consider that "weak GRADE recommendations" could be interpreted as "management suggestions" and treated with appropriate caution. A further limitation is that several pathologies have been grouped together as one syndrome, although this relates to both the rarity of the syndrome and the lack of high-quality evidence: further research is desperately needed. In particular, only then will we learn whether PAH-targeted therapy such as use of PDE5 inhibitors or endothelinreceptor antagonists, so effective in idiopathic $\mathrm{PAH}$, have a role in the ICU setting.

\section{Key messages}

- Pulmonary hypertension (PH) and associated right ventricular (RV) failure are associated with worse outcomes in critical care, and because of nonspecific presenting symptoms and signs, may be difficult to recognize: echocardiography is a very useful initial test, and invasive monitoring may be helpful in some cases for more continuous monitoring and accurate measurement of pulmonary vascular resistance.

- Volume loading of the right ventricle may worsen its performance: all fluid challenges should be closely monitored.

- It is essential to maintain adequate aortic root pressure to prevent the onset of RV ischemia. Vasopressors are useful in this setting, including low-dose norepinephrine as a first-line agent. Low-dose vasopressin may also be useful in some resistant cases but has adverse myocardial effects at higher doses. Potentially useful inotropes in RV failure include dobutamine and those with additional pulmonary vasodilating effects, including PDE III inhibitors, although co-administration with pressors is often necessary. The effects of any vasoactive drug may be unpredictable in an individual and require close clinical observation of circulatory performance, potentially assisted by echocardiography. 
- Pulmonary vasodilators are useful to reduce RV afterload in several ICU settings, including PH and RV failure after cardiac surgery. Systemic administration may worsen systemic hemodynamics and oxygenation because of ventilation-perfusion mismatching.

- The use of mechanical therapies to manage acute $\mathrm{PH}$ and enhance RV performance is expanding, although with evidence currently limited to case series, and may be useful in experienced centers to ameliorate RV failure while awaiting definitive therapy.

\section{Additional material}

\section{Additional file 1:}

Population, Intervention, Comparison and Outcome (PICO) evidence tables. This file contains structured detail for all studies included in the systematic review. According to GRADE method guidelines, a series of eight study questions was devised to approach the questions posed by the systematic literature review. The PICO table then describes each study according to the study type, the population studied, the intervention applied, the nature of the comparison or control group, and the studied outcome of interest appropriate to the study question. The final column grades the evidence according to the GRADE evidence level as very low-, low-, moderate-, or highlevel evidence $[80,81]$.

\begin{abstract}
Abbreviations
ACP: acute cor pulmonale; ARDS: acute respiratory distress syndrome; AVP: arginine vasopressin; CAMP: cyclic adenosine 3',5'-cyclic monophosphate; cGMP: cyclic guanosine 3',5'-cyclic monophosphate; Cl: cardiac index; CO: cardiac output; COPD: chronic obstructive pulmonary disease; CPB: cardiopulmonary bypass; CVP: central venous pressure; ECMO: extracorporeal membrane oxygenation; ICU: intensive care unit; IABP: intraaortic balloon pump; LV: left ventricle; MVR: mitral valve replacement; NE: norepinephrine; NO: nitric oxide; PAC: pulmonary artery catheter; PAH: pulmonary arterial hypertension; PAOP: pulmonary arterial occlusion pressure; PDE: phosphodiesterase; $\mathrm{PE}$ : pulmonary embolism; $\mathrm{PGE}_{1}$ : prostaglandin $\mathrm{E}_{1} ; \mathrm{PH}$ : pulmonary hypertension; PHE: phenylephrine; PVR: pulmonary vascular resistance; RV: right ventricle; RVEF: right ventricular ejection fraction; RVF: right ventricular failure; $\mathrm{SvO}_{2}$ : mixed venous oxygen saturation; SVR: systemic vascular resistance; TEE: transesophageal echocardiography; TR: tricuspid regurgitation; V/Q mismatch: ventilation/perfusion mismatch.
\end{abstract}

\section{Acknowledgements}

SJB is grateful for the support of the UK NIHR Biomedical Research Centre Scheme.

\section{Author details}

${ }^{1}$ Department of Critical Care, National Heart and Lung Institute, Imperial College London, Royal Brompton Hospital, Sydney Street, London SW3 6NP, UK. ${ }^{2}$ Centre for Perioperative Medicine and Critical Care Research, Imperial College Healthcare NHS Trust, Hammersmith Hospital, Du Cane Road, London W12 OHS, UK.

\section{Authors' contributions}

LCP and SJB conceived of the review and participated in its design. LCP and SJW carried out the literature search and drafted the initial manuscript. All authors read and approved the final manuscript.

\section{Competing interests}

LCP has received honoraria from Encysive Pharmaceuticals. SJW has received honoraria from Actelion Pharmaceuticals. SJB has received support for clinical trials from Pfizer, Astra Zeneca, and Baxter Healthcare.

Received: 16 March 2010 Revised: 30 May 2010

Accepted: 21 September 2010 Published: 21 September 2010

\section{References}

1. Snow RL, Davies P, Pontoppidan H, Zapol WM, Reid L: Pulmonary vascular remodeling in adult respiratory distress syndrome. Am Rev Respir Dis 1982, 126:887-892

2. Gillis CN, Pitt BR, Wiedemann HP, Hammond GL: Depressed prostaglandin $\mathrm{E} 1$ and 5-hydroxytryptamine removal in patients with adult respiratory distress syndrome. Am Rev Respir Dis 1986, 134:739-744.

3. Greene R, Zapol WM, Snider MT, Reid L, Snow R, O'Connell RS, Novelline RA: Early bedside detection of pulmonary vascular occlusion during acute respiratory failure. Am Rev Respir Dis 1981, 124:593-601.

4. Piazza G, Goldhaber SZ: The acutely decompensated right ventricle: pathways for diagnosis and management. Chest 2005, 128:1836-1852.

5. Jacobs AK, Leopold JA, Bates E, Mendes LA, Sleeper LA, White H, Davidoff R, Boland J, Modur S, Forman R, Hochman JS: Cardiogenic shock caused by right ventricular infarction: a report from the SHOCK registry. J Am Coll Cardiol 2003, 41:1273-1279.

6. Kimchi A, Ellrodt AG, Berman DS, Riedinger MS, Swan HJ, Murata GH: Right ventricular performance in septic shock: a combined radionuclide and hemodynamic study. J Am Coll Cardiol 1984, 4:945-951.

7. Parker MM, McCarthy KE, Ognibene FP, Parrillo JE: Right ventricular dysfunction and dilatation, similar to left ventricular changes, characterize the cardiac depression of septic shock in humans. Chest 1990, 97:126-131.

8. Rubin LJ: Primary pulmonary hypertension. N Engl J Med 1997, 336:111-117.

9. Berger M, Haimowitz A, Van Tosh A, Berdoff RL, Goldberg E: Quantitative assessment of pulmonary hypertension in patients with tricuspid regurgitation using continuous wave Doppler ultrasound. J Am Coll Cardiol 1985, 6:359-365.

10. Dabestani A, Mahan G, Gardin JM, Takenaka K, Burn C, Allfie A, Henry WL: Evaluation of pulmonary artery pressure and resistance by pulsed Doppler echocardiography. Am J Cardiol 1987, 59:662-668.

11. Bossone E, Bodini BD, Mazza A, Allegra L: Pulmonary arterial hypertension: the key role of echocardiography. Chest 2005, 127:1836-1843.

12. Forfia PR, Fisher MR, Mathai SC, Housten-Harris T, Hemnes AR, Borlaug BA, Chamera E, Corretti MC, Champion HC, Abraham TP, Girgis RE, Hassoun PM: Tricuspid annular displacement predicts survival in pulmonary hypertension. Am J Respir Crit Care Med 2006, 174:1034-1041.

13. Lang RM, Bierig M, Devereux RB, Flachskampf FA, Foster E, Pellikka PA, Picard MH, Roman MJ, Seward J, Shanewise JS, Solomon SD, Spencer KT, Sutton MS, Stewart WJ: Recommendations for chamber quantification: a report from the American Society of Echocardiography's Guidelines and Standards Committee and the Chamber Quantification Writing Group, developed in conjunction with the European Association of Echocardiography, a branch of the European Society of Cardiology. J Am Soc Echocardiogr 2005, 18:1440-1463.

14. Le Tulzo Y, Seguin P, Gacouin A, Camus C, Suprin E, Jouannic I, Thomas R: Effects of epinephrine on right ventricular function in patients with severe septic shock and right ventricular failure: a preliminary descriptive study. Intensive Care Med 1997, 23:664-670.

15. Vieillard-Baron A, Prin S, Chergui K, Dubourg O, Jardin F: Echo-Doppler demonstration of acute cor pulmonale at the bedside in the medical intensive care unit. Am J Respir Crit Care Med 2002, 166:1310-1319.

16. Jardin F, Dubourg O, Bourdarias JP: Echocardiographic pattern of acute cor pulmonale. Chest 1997, 111:209-217. 
17. Fischer $L G$, Van Aken $H$, Burkle H: Management of pulmonary hypertension: physiological and pharmacological considerations for anesthesiologists. Anesth Analg 2003, 96:1603-1616.

18. Ocal A, Kiris I, Erdinc M, Peker O, Yavuz T, Ibrisim E: Efficiency of prostacyclin in the treatment of protamine-mediated right ventricular failure and acute pulmonary hypertension. Tohoku J Exp Med 2005, 207:51-58.

19. Sibbald WJ, Paterson NA, Holliday RL, Anderson RA, Lobb TR, Duff JH: Pulmonary hypertension in sepsis: measurement by the pulmonary arterial diastolic-pulmonary wedge pressure gradient and the influence of passive and active factors. Chest 1978, 73:583-591.

20. Wort SJ, Evans TW: The role of the endothelium in modulating vascular control in sepsis and related conditions. Br Med Bull 1999, 55:30-48.

21. Albertini M, Clement MG, Hussain SN: Role of endothelin ETA receptors in sepsis-induced mortality, vascular leakage, and tissue injury in rats. Eur $J$ Pharmacol 2003, 474:129-135.

22. Rossi P, Persson B, Boels PJ, Arner A, Weitzberg E, Oldner A: Endotoxemic pulmonary hypertension is largely mediated by endothelin-induced venous constriction. Intensive Care Med 2008, 34:873-880.

23. Osman D, Monnet X, Castelain V, Anguel N, Warszawski J, Teboul JL, Richard C: Incidence and prognostic value of right ventricular failure in acute respiratory distress syndrome. Intensive Care Med 2009, 35:69-76.

24. Vieillard-Baron A, Schmitt JM, Augarde R, Fellahi JL, Prin S, Page B, Beauchet $A$, Jardin F: Acute cor pulmonale in acute respiratory distress syndrome submitted to protective ventilation: incidence, clinical implications, and prognosis. Crit Care Med 2001, 29:1551-1555.

25. Vieillard-Baron A, Page B, Augarde R, Prin S, Qanadli S, Beauchet A, Dubourg $O$, Jardin F: Acute cor pulmonale in massive pulmonary embolism: incidence, echocardiographic pattern, clinical implications and recovery rate. Intensive Care Med 2001, 27:1481-1486.

26. Ribeiro $A$, Lindmarker $P$, Juhlin-Dannfelt $A$, Johnsson $H$, Jorfeldt $L$ : Echocardiography Doppler in pulmonary embolism: right ventricular dysfunction as a predictor of mortality rate. Am Heart J 1997, 134:479-487.

27. Kasper W, Konstantinides S, Geibel A, Tiede N, Krause T, Just H: Prognostic significance of right ventricular afterload stress detected by echocardiography in patients with clinically suspected pulmonary embolism. Heart 1997, 77:346-349.

28. Clowes GH Jr, Farrington GH, Zuschneid W, Cossette GR, Saravis C: Circulating factors in the etiology of pulmonary insufficiency and right heart failure accompanying severe sepsis (peritonitis). Ann Surg 1970, 171:663-678.

29. Monchi M, Bellenfant F, Cariou A, Joly LM, Thebert D, Laurent I, Dhainaut JF, Brunet F: Early predictive factors of survival in the acute respiratory distress syndrome: a multivariate analysis. Am J Respir Crit Care Med 1998, 158:1076-1081

30. Squara P, Dhainaut JF, Artigas A, Carlet J: Hemodynamic profile in severe ARDS: results of the European Collaborative ARDS Study. Intensive Care Med 1998, 24:1018-1028.

31. Leeman M: Pulmonary hypertension in acute respiratory distress syndrome. Monaldi Arch Chest Dis 1999, 54:146-149.

32. Ramakrishna G, Sprung J, Ravi BS, Chandrasekaran K, McGoon MD: Impact of pulmonary hypertension on the outcomes of noncardiac surgery: predictors of perioperative morbidity and mortality. J Am Coll Cardiol 2005, 45:1691-1699.

33. Minai $O A$, Venkateshiah $S B$, Arroliga $A C$ : Surgical intervention in patients with moderate to severe pulmonary arterial hypertension. Conn Med 2006, 70:239-243.

34. Lai HC, Lai HC, Wang KY, Lee WL, Ting CT, Liu TJ: Severe pulmonary hypertension complicates postoperative outcome of non-cardiac surgery. Br J Anaesth 2007, 99:184-190.

35. Krowka MJ, Plevak DJ, Findlay JY, Rosen CB, Wiesner RH, Krom RA: Pulmonary hemodynamics and perioperative cardiopulmonary-related mortality in patients with portopulmonary hypertension undergoing liver transplantation. Liver Transp/ 2000, 6:443-450.

36. Price $L C$, Montani $D$, Jais $X$, Dick JR, Simonneau G, Sitbon O, Mercier FJ, Humbert M: Non-cardiothoracic non-obstetric surgery in mild-moderate pulmonary hypertension: perioperative management of 28 consecutive individual cases. Eur Respir J 2010, 35:1294-1302.

37. Bonnin $M$, Mercier FJ, Sitbon $\mathrm{O}$, Roger-Christoph $\mathrm{S}$, Jais $\mathrm{X}$, Humbert $\mathrm{M}$, Audibert F, Frydman R, Simonneau G, Benhamou D: Severe pulmonary hypertension during pregnancy: mode of delivery and anesthetic management of 15 consecutive cases. Anesthesiology 2005, 102:1133-1137, discussion 1135A-1136A.

38. Bedard E, Dimopoulos K, Gatzoulis MA: Has there been any progress made on pregnancy outcomes among women with pulmonary arterial hypertension? Eur Heart J 2009, 30:256-265.

39. Bernstein $A D$, Parsonnet $\mathrm{V}$ : Bedside estimation of risk as an aid for decision-making in cardiac surgery. Ann Thorac Surg 2000, 69:823-828.

40. Subramaniam K, Yared JP: Management of pulmonary hypertension in the operating room. Semin Cardiothorac Vasc Anesth 2007, 11:119-136.

41. Morgan JA, John R, Lee BJ, Oz MC, Naka Y: Is severe right ventricular failure in left ventricular assist device recipients a risk factor for unsuccessful bridging to transplant and post-transplant mortality. Ann Thorac Surg 2004, 77:859-863.

42. Price LC, Montani D, Jais X, Dick JR, Simonneau G, Sitbon O, Mercier FJ, Humbert M: Noncardiothoracic nonobstetric surgery in mild-to-moderate pulmonary hypertension. Eur Respir J 35:1294-1302.

43. McIntyre KM, Sasahara AA: Determinants of right ventricular function and hemodynamics after pulmonary embolism. Chest 1974, 65:534-543.

44. Kerbaul F, Rondelet B, Motte S, Fesler P, Hubloue I, Ewalenko P, Naeije R, Brimioulle $S$ : Effects of norepinephrine and dobutamine on pressure load-induced right ventricular failure. Crit Care Med 2004, 32:1035-1040.

45. Nath J, Foster E, Heidenreich PA: Impact of tricuspid regurgitation on long-term survival. J Am Coll Cardiol 2004, 43:405-409.

46. Pinsky MR: Heart-lung interactions. Curr Opin Crit Care 2007, 13:528-531.

47. Sibbald WJ, Driedger AA: Right ventricular function in acute disease states: pathophysiologic considerations. Crit Care Med 1983, 11:339-345.

48. Pinsky MR: Recent advances in the clinical application of heart-lung interactions. Curr Opin Crit Care 2002, 8:26-31.

49. Stojnic BB, Brecker SJ, Xiao HB, Helmy SM, Mbaissouroum M, Gibson DG: Left ventricular filling characteristics in pulmonary hypertension: a new mode of ventricular interaction. Br Heart J 1992, 68:16-20.

50. Taylor RR, Covell JW, Sonnenblick EH, Ross J: Dependence of ventricular distensibility on filling of the opposite ventricle. Am J Physiol 1967, 213:711-718.

51. Fellahi JL, Valtier B, Beauchet A, Bourdarias JP, Jardin F: Does positive endexpiratory pressure ventilation improve left ventricular function? A comparative study by transesophageal echocardiography in cardiac and noncardiac patients. Chest 1998, 114:556-562.

52. Louie EK, Lin SS, Reynertson SI, Brundage BH, Levitsky S, Rich S: Pressure and volume loading of the right ventricle have opposite effects on left ventricular ejection fraction. Circulation 1995, 92:819-824.

53. Louie EK, Rich S, Brundage BH: Doppler echocardiographic assessment of impaired left ventricular filling in patients with right ventricular pressure overload due to primary pulmonary hypertension. J Am Coll Cardiol 1986, 8:1298-1306.

54. Ricciardi MJ, Bossone E, Bach DS, Armstrong WF, Rubenfire M: Echocardiographic predictors of an adverse response to a nifedipine trial in primary pulmonary hypertension: diminished left ventricular size and leftward ventricular septal bowing. Chest 1999, 116:1218-1223.

55. Vlahakes GJ, Turley K, Hoffman Jl: The pathophysiology of failure in acute right ventricular hypertension: hemodynamic and biochemical correlations. Circulation 1981, 63:87-95.

56. Weitzenblum E: Chronic cor pulmonale. Heart 2003, 89:225-230.

57. Blaise G, Langleben D, Hubert B: Pulmonary arterial hypertension: pathophysiology and anesthetic approach. Anesthesiology 2003, 99:1415-1432.

58. Chin KM, Kim NH, Rubin L: The right ventricle in pulmonary hypertension. Coron Artery Dis 2005, 16:13-18.

59. Hadian M, Pinsky MR: Evidence-based review of the use of the pulmonary artery catheter impact data and complications. Crit Care 2006, 10 Suppl 3:S8.

60. Handa $\mathrm{F}$, Kyo SE, Miyao $\mathrm{H}$ : Reduction in the use of pulmonary artery catheter for cardiovascular surgery. Masui 2003, 52:420-423.

61. Mebazaa A, Pitsis AA, Rudiger A, Toller W, Longrois D, Ricksten SE, Bobek I, De Hert S, Wieselthaler G, Schirmer U, von Segesser LK, Sander M, Poldermans D, Ranucci M, Karpati PC, Wouters P, Seeberger M, Schmid ER, Weder W, Follath F: Clinical review: practical recommendations on the management of perioperative heart failure in cardiac surgery. Crit Care 2010, 14:201. 
62. Zapol WM, Kobayashi K, Snider MT, Greene R, Laver MB: Vascular obstruction causes pulmonary hypertension in severe acute respiratory failure. Chest 1977, 71:306-307.

63. Vieillard-Baron A: Assessment of right ventricular function. Curr Opin Crit Care 2009, 15:254-260.

64. Gadhinglajkar S, Sreedhar R, Jayakumar K, Misra M, Ganesh S, Panicker V: Intra-operative assessment of biventricular function using transesophageal echocardiography pre/post-pulmonary thromboembolectomy in patient with chronic thromboembolic pulmonary hypertension. Ann Card Anaesth 2009, 12:140-145.

65. Serra E, Feltracco P, Barbieri S, Forti A, Ori C: Transesophageal echocardiography during lung transplantation. Transplant Proc 2007 39:1981-1982.

66. Currie PJ, Seward JB, Chan KL, Fyfe DA, Hagler DJ, Mair DD, Reeder GS, Nishimura RA, Tajik AJ: Continuous wave Doppler determination of right ventricular pressure: a simultaneous Doppler-catheterization study in 127 patients. J Am Coll Cardiol 1985, 6:750-756.

67. Yock PG, Popp RL: Noninvasive estimation of right ventricular systolic pressure by Doppler ultrasound in patients with tricuspid regurgitation. Circulation 1984, 70:657-662.

68. Nagaya N, Nishikimi T, Uematsu M, Satoh T, Kyotani S, Sakamaki F, Kakishita M, Fukushima K, Okano Y, Nakanishi N, Miyatake K, Kangawa K: Plasma brain natriuretic peptide as a prognostic indicator in patients with primary pulmonary hypertension. Circulation 2000, 102:865-870

69. Logeart D, Lecuyer L, Thabut G, Tabet JY, Tartiere JM, Chavelas C, Bonnin F, Stievenart JL, Solal AC: Biomarker-based strategy for screening right ventricular dysfunction in patients with non-massive pulmonary embolism. Intensive Care Med 2007, 33:286-292.

70. Lega JC, Lacasse Y, Lakhal L, Provencher S: Natriuretic peptides and troponins in pulmonary embolism: a meta-analysis. Thorax 2009, 64:869-875.

71. Mehta NJ, Jani K, Khan IA: Clinical usefulness and prognostic value of elevated cardiac troponin I levels in acute pulmonary embolism. Am Heart J 2003, 145:821-825.

72. Clark BJ, Brown NJ, Moss M, Bull TM: Increased serum BNP concentrations are associated with pulmonary vascular dysfunction in patients with acute lung injury. Am J Respir Crit Care Med 2010, 181:A2582.

73. Alpert JS, Smith R, Carlson J, Ockene IS, Dexter L, Dalen JE: Mortality in patients treated for pulmonary embolism. JAMA 1976, 236:1477-1480.

74. Goldhaber SZ, Haire WD, Feldstein ML, Miller M, Toltzis R, Smith JL, Taveira da Silva AM, Come PC, Lee RT, Parker JA: Alteplase versus heparin in acute pulmonary embolism: randomised trial assessing right-ventricular function and pulmonary perfusion. Lancet 1993, 341:507-511.

75. Goldhaber SZ, Morpurgo M: Diagnosis, treatment, and prevention of pulmonary embolism: report of the WHO/International Society and Federation of Cardiology Task Force. JAMA 1992, 268:1727-1733.

76. Pengo V, Lensing AW, Prins MH, Marchiori A, Davidson BL, Tiozzo F, Albanese P, Biasiolo A, Pegoraro C, lliceto S, Prandoni P: Incidence of chronic thromboembolic pulmonary hypertension after pulmonary embolism. N Engl J Med 2004, 350:2257-2264.

77. Dalen JE, Alpert JS: Natural history of pulmonary embolism. Prog Cardiovasc Dis 1975, 17:259-270.

78. Lualdi JC, Goldhaber SZ: Right ventricular dysfunction after acute pulmonary embolism: pathophysiologic factors detection, and therapeutic implications. Am Heart J 1995, 130:1276-1282.

79. Bhorade S, Christenson J, O'Connor M, Lavoie A, Pohlman A, Hall JB: Response to inhaled nitric oxide in patients with acute right heart syndrome. Am J Respir Crit Care Med 1999, 159:571-579.

80. Guyatt GH, Oxman AD, Kunz R, Vist GE, Falck-Ytter Y, Schunemann HJ: What is "quality of evidence" and why is it important to clinicians? BMJ 2008, 336:995-998

81. Guyatt GH, Oxman AD, Vist GE, Kunz R, Falck-Ytter $Y$, Alonso-Coello $P$, Schunemann HJ: GRADE: an emerging consensus on rating quality of evidence and strength of recommendations. BMJ 2008, 336:924-926.

82. Gan CT, Lankhaar JW, Marcus JT, Westerhof N, Marques KM, Bronzwaer JG, Boonstra A, Postmus PE, Vonk-Noordegraaf A: Impaired left ventricular filling due to right-to-left ventricular interaction in patients with pulmonary arterial hypertension. Am J Physiol Heart Circ Physiol 2006, 290: H1528-H1533.
83. Zamanian RT, Haddad F, Doyle RL, Weinacker AB: Management strategies for patients with pulmonary hypertension in the intensive care unit. Crit Care Med 2007, 35:2037-2050.

84. Reuse C, Vincent JL, Pinsky MR: Measurements of right ventricular volumes during fluid challenge. Chest 1990, 98:1450-1454.

85. Naeije R, Vachiery JL: Medical therapy of pulmonary hypertension conventional therapies. Clin Chest Med 2001, 22:517-527.

86. Layish DT, Tapson VF: Pharmacologic hemodynamic support in massive pulmonary embolism. Chest 1997, 111:218-224.

87. James KB, Stelmach K, Armstrong R, Young JB, Fouad-Tarazi F: Plasma volume and outcome in pulmonary hypertension. Tex Heart Inst J 2003, 30:305-307.

88. Mathru M, Venus B, Smith RA, Shirakawa Y, Sugiura A: Treatment of low cardiac output complicating acute pulmonary hypertension in normovolemic goats. Crit Care Med 1986, 14:120-124.

89. Molloy WD, Lee KY, Girling L, Schick U, Prewitt RM: Treatment of shock in a canine model of pulmonary embolism. Am Rev Respir Dis 1984, 130:870-874.

90. Ghignone $M$, Girling L, Prewitt RM: Volume expansion versus norepinephrine in treatment of a low cardiac output complicating an acute increase in right ventricular afterload in dogs. Anesthesiology 1984 60:132-135.

91. Belenkie I, Dani R, Smith ER, Tyberg JV: Effects of volume loading during experimental acute pulmonary embolism. Circulation 1989, 80:178-188.

92. Mercat A, Diehl JL, Meyer G, Teboul JL, Sors H: Hemodynamic effects of fluid loading in acute massive pulmonary embolism. Crit Care Med 1999, 27:540-544.

93. Redl G, Germann P, Plattner H, Hammerle A: Right ventricular function in early septic shock states. Intensive Care Med 1993, 19:3-7.

94. Schneider AJ, Teule GJ, Groeneveld AB, Nauta J, Heidendal GA, Thijs LG: Biventricular performance during volume loading in patients with early septic shock, with emphasis on the right ventricle: a combined hemodynamic and radionuclide study. Am Heart J 1988, 116:103-112.

95. Siva A, Shah AM: Moderate mitral stenosis in pregnancy: the haemodynamic impact of diuresis. Heart 2005, 91:e3.

96. Ducas J, Prewitt RM: Pathophysiology and therapy of right ventricular dysfunction due to pulmonary embolism. Cardiovasc Clin 1987, 17:191-202.

97. Mebazaa A, Karpati P, Renaud E, Algotsson L: Acute right ventricular failure: from pathophysiology to new treatments. Intensive Care Med 2004, 30:185-196.

98. Goldhaber SZ: The approach to massive pulmonary embolism. Semin Respir Crit Care Med 2000, 21:555-561.

99. Forrest P: Anaesthesia and right ventricular failure. Anaesth Intensive Care 2009, 37:370-385.

100. Kwak YL, Lee CS, Park YH, Hong YW: The effect of phenylephrine and norepinephrine in patients with chronic pulmonary hypertension. Anaesthesia 2002, 57:9-14.

101. Dunser MW, Hasibeder WR: Sympathetic overstimulation during critica illness: adverse effects of adrenergic stress. J Intensive Care Med 2009, 24:293-316.

102. Bergofsky EH: Humoral control of the pulmonary circulation. Annu Rev Physiol 1980, 42:221-233.

103. Hanson EL, O'Connor NE, Drinker PA: Hemodynamic response to controlled ventilation during hypoxia in man and animals. Surg Forum 1972, 23:207-209.

104. Tourneux P, Rakza T, Bouissou A, Krim G, Storme L: Pulmonary circulatory effects of norepinephrine in newborn infants with persistent pulmonary hypertension. J Pediatr 2008, 153:345-349.

105. Morelli A, Ertmer C, Rehberg S, Lange M, Orecchioni A, Cecchini V, Bachetoni A, D'Alessandro M, Van Aken $H$, Pietropaoli P, Westphal M: Continuous terlipressin versus vasopressin infusion in septic shock (TERLIVAP): a randomized, controlled pilot study. Crit Care 2009, 13:R130.

106. Schreuder WO, Schneider AJ, Groeneveld AB, Thijs LG: Effect of dopamine vs norepinephrine on hemodynamics in septic shock: emphasis on right ventricular performance. Chest 1989, 95:1282-1288.

107. Ducas J, Duval D, Dasilva H, Boiteau P, Prewitt RM: Treatment of canine pulmonary hypertension: effects of norepinephrine and isoproterenol on pulmonary vascular pressure-flow characteristics. Circulation 1987, 75:235-242. 
108. Hirsch LJ, Rooney MW, Wat SS, Kleinmann B, Mathru M: Norepinephrine and phenylephrine effects on right ventricular function in experimental canine pulmonary embolism. Chest 1991, 100:796-801.

109. Martin C, Perrin G, Saux P, Papazian L, Gouin F: function Effects of norepinephrine on right ventricular in septic shock patients. Intensive Care Med 1994, 20:444-447.

110. Bertolissi M, Bassi F, Da Broi U: Norepinephrine can be useful for the treatment of right ventricular failure combined with acute pulmonary hypertension and systemic hypotension: a case report. Minerva Anestesiol 2001, 67:79-84.

111. Rich S, Gubin S, Hart K: The effects of phenylephrine on right ventricular performance in patients with pulmonary hypertension. Chest 1990, 98:1102-1106.

112. Eichinger MR, Walker BR: Enhanced pulmonary arterial dilation to arginine vasopressin in chronically hypoxic rats. Am J Physiol 1994, 267: $\mathrm{H} 2413-\mathrm{H} 2419$.

113. Walker BR, Haynes J Jr, Wang HL, Voelkel NF: Vasopressin-induced pulmonary vasodilation in rats. Am J Physiol 1989, 257:H415-H422.

114. Evora PR, Pearson PJ, Schaff HV: Arginine vasopressin induces endothelium-dependent vasodilatation of the pulmonary artery: V1receptor-mediated production of nitric oxide. Chest 1993, 103:1241-1245.

115. Jeon Y, Ryu JH, Lim YJ, Kim CS, Bahk JH, Yoon SZ, Choi JY: Comparative hemodynamic effects of vasopressin and norepinephrine after milrinone-induced hypotension in off-pump coronary artery bypass surgical patients. Eur J Cardiothorac Surg 2006, 29:952-956.

116. Tayama E, Ueda T, Shojima T, Akasu K, Oda T, Fukunaga S, Akashi H, Aoyagi S: Arginine vasopressin is an ideal drug after cardiac surgery for the management of low systemic vascular resistant hypotension concomitant with pulmonary hypertension. Interact Cardiovasc Thorac Surg 2007, 6:715-719.

117. Braun EB, Palin CA, Hogue CW: Vasopressin during spinal anesthesia in a patient with primary pulmonary hypertension treated with intravenous epoprostenol. Anesth Analg 2004, 99:36-37.

118. Price LC, Forrest P, Sodhi V, Adamson DL, Nelson-Piercy C, Lucey M, Howard LS: Use of vasopressin after caesarean section in idiopathic pulmonary arterial hypertension. Br J Anaesth 2007, 99:552-555.

119. Smith AM, Elliot CM, Kiely DG, Channer KS: The role of vasopressin in cardiorespiratory arrest and pulmonary hypertension. QJM 2006, 99:127-133.

120. Russell JA, Walley KR, Singer J, Gordon AC, Hebert PC, Cooper DJ, Holmes CL, Mehta S, Granton JT, Storms MM, Cook DJ, Presneill JJ, Ayers D: Vasopressin versus norepinephrine infusion in patients with septic shock. N Engl J Med 2008, 358:877-887.

121. Torgersen C, Dunser MW, Wenzel V, Jochberger S, Mayr V, Schmittinger CA, Lorenz I, Schmid S, Westphal M, Grander W, Luckner G: Comparing two different arginine vasopressin doses in advanced vasodilatory shock: a randomized, controlled, open-label trial. Intensive Care Med 2010, 36:57-65.

122. Luckner G, Mayr VD, Jochberger S, Wenzel V, Ulmer H, Hasibeder WR, Dunser MW: Comparison of two dose regimens of arginine vasopressin in advanced vasodilatory shock. Crit Care Med 2007, 35:2280-2285.

123. Gold J, Cullinane S, Chen J, Seo S, Oz MC, Oliver JA, Landry DW: Vasopressin in the treatment of milrinone-induced hypotension in severe heart failure. Am J Cardiol 2000, 85:506-508, A511.

124. Argenziano $M$, Choudhri AF, Oz MC, Rose EA, Smith CR, Landry DW: A prospective randomized trial of arginine vasopressin in the treatment of vasodilatory shock after left ventricular assist device placement. Circulation 1997, 96:II-286-II-290.

125. Vida VL, Mack R, Castaneda AR: The role of vasopressin in treating systemic inflammatory syndrome complicated by right ventricular failure. Cardiol Young 2005, 15:88-90.

126. Scheurer MA, Bradley SM, Atz AM: Vasopressin to attenuate pulmonary hypertension and improve systemic blood pressure after correction of obstructed total anomalous pulmonary venous return. J Thorac Cardiovasc Surg 2005, 129:464-466.

127. Wang HJ, Wong CS, Chiang CY, Yeh CC, Cherng CH, Ho ST, Wu CT: Lowdose vasopressin infusion can be an alternative in treating patients with refractory septic shock combined with chronic pulmonary hypertension: a case report. Acta Anaesthesio/ Sin 2003, 41:77-80.

128. Jain RL, Horn EM: Peripheral vasodilation complicated by pulmonary hypertension: a role for vasopressin. Am J Respir Crit Care Med 2008, 177 A919.
129. Holmes CL, Walley KR, Chittock DR, Lehman T, Russell JA: The effects of vasopressin on hemodynamics and renal function in severe septic shock: a case series. Intensive Care Med 2001, 27:1416-1421.

130. Dunser MW, Mayr AJ, Ulmer H, Knotzer H, Sumann G, Pajk W, Friesenecker B, Hasibeder WR: Arginine vasopressin in advanced vasodilatory shock: a prospective, randomized, controlled study. Circulation 2003, 107:2313-2319.

131. Dunser MW, Mayr AJ, Stallinger A, Ulmer H, Ritsch N, Knotzer H, Pajk W, Mutz NJ, Hasibeder WR: Cardiac performance during vasopressin infusion in postcardiotomy shock. Intensive Care Med 2002, 28:746-751.

132. Lauzier F, Levy B, Lamarre $P$, Lesur $O$ : Vasopressin or norepinephrine in early hyperdynamic septic shock: a randomized clinical trial. Intensive Care Med 2006, 32:1782-1789.

133. Varma S, Jaju BP, Bhargava KP: Mechanism of vasopressin-induced bradycardia in dogs. Circ Res 1969, 24:787-792.

134. Naeije R, Hallemans R, Mols P, Melot C, Reding P: Effect of vasopressin and somatostatin on hemodynamics and blood gases in patients with liver cirrhosis. Crit Care Med 1982, 10:578-582.

135. Mols P, Hallemans R, Van Kuyk M, Melot C, Lejeune P, Ham H, Vertongen F, Naeije R: Hemodynamic effects of vasopressin, alone and in combination with nitroprusside, in patients with liver cirrhosis and portal hypertension. Ann Surg 1984, 199:176-181.

136. Migotto WH, Dahi H: Effects of vasopressin on hemodynamics in cardiogenic shock. Chest 2005, 128:168S.

137. Walker BR, Childs ME, Adams EM: Direct cardiac effects of vasopressin: role of V1- and V2-vasopressinergic receptors. Am J Physiol 1988, 255 $\mathrm{H} 261-\mathrm{H} 265$.

138. Leather HA, Segers P, Berends N, Vandermeersch E, Wouters PF: Effects of vasopressin on right ventricular function in an experimental model of acute pulmonary hypertension. Crit Care Med 2002, 30:2548-2552.

139. Indrambarya T, Boyd JH, Wang Y, McConechy M, Walley KR: Low-dose vasopressin infusion results in increased mortality and cardiac dysfunction following ischemia-reperfusion injury in mice. Crit Care 2009, 13:R98.

140. Tisdale JE, Patel R, Webb CR, Borzak S, Zarowitz BJ: Electrophysiologic and proarrhythmic effects of intravenous inotropic agents. Prog CardiovasC Dis 1995, 38:167-180.

141. Holloway EL, Polumbo RA, Harrison DC: Acute circulatory effects of dopamine in patients with pulmonary hypertension. Br Heart J 1975, 37:482-485.

142. Liet JM, Boscher C, Gras-Leguen C, Gournay V, Debillon T, Roze JC: Dopamine effects on pulmonary artery pressure in hypotensive preterm infants with patent ductus arteriosus. J Pediatr 2002, 140:373-375.

143. Leier CV, Heban PT, Huss P, Bush CA, Lewis RP: Comparative systemic and regional hemodynamic effects of dopamine and dobutamine in patients with cardiomyopathic heart failure. Circulation 1978, 58:466-475.

144. Lejeune P, Naeije R, Leeman M, Melot C, Deloof T, Delcroix M: Effects of dopamine and dobutamine on hyperoxic and hypoxic pulmonary vascular tone in dogs. Am Rev Respir Dis 1987, 136:29-35.

145. Schreuder WO, Schneider AJ, Groeneveld AB, Thijs LG: The influence of catecholamines on right ventricular function in septic shock. Intensive Care Med 1988, 14 Suppl 2:492-495.

146. De Backer D, Biston P, Devriendt J, Madl C, Chochrad D, Aldecoa C, Brasseur A, Defrance P, Gottignies P, Vincent JL: Comparison of dopamine and norepinephrine in the treatment of shock. N Engl J Med 2010, 362:779-789.

147. Barrington KJ, Finer NN, Chan WK: A blind, randomized comparison of the circulatory effects of dopamine and epinephrine infusions in the newborn piglet during normoxia and hypoxia. Crit Care Med 1995 23:740-748.

148. Stobierska-Dzierzek B, Awad H, Michler RE: The evolving management of acute right-sided heart failure in cardiac transplant recipients. J Am Coll Cardiol 2001, 38:923-931.

149. Prielipp RC, McLean R, Rosenthal MH, Pearl RG: Hemodynamic profiles of prostaglandin E1, isoproterenol, prostacyclin, and nifedipine in experimental porcine pulmonary hypertension. Crit Care Med 1991, 19:60-67.

150. Acosta F, Sansano T, Palenciano CG, Falcon L, Domenech P, Robles R, Bueno FS, Ramirez $P$, Parrilla P: Effects of dobutamine on right ventricular function and pulmonary circulation in pulmonary hypertension during liver transplantation. Transplant Proc 2005, 37:3869-3870. 
151. Ferrario M, Poli A, Previtali M, Lanzarini L, Fetiveau R, Diotallevi $P$, Mussini A, Montemartini C: Hemodynamics of volume loading compared with dobutamine in severe right ventricular infarction. Am J Cardiol 1994, 74:329-333.

152. Sztrymf B, Souza R, Bertoletti L, Jais X, Sitbon O, Price LC, Simonneau G, Humbert M: Prognostic factors of acute heart failure in patients with pulmonary arterial hypertension. Eur Respir J 2010, 35:1286-1293.

153. Vizza CD, Rocca GD, Roma AD, lacoboni C, Pierconti F, Venuta F, Rendina $E$, Schmid G, Pietropaoli P, Fedele F: Acute hemodynamic effects of inhaled nitric oxide, dobutamine and a combination of the two in patients with mild to moderate secondary pulmonary hypertension. Crit Care 2001, 5:355-361.

154. Pagnamenta A, Fesler P, Vandinivit A, Brimioulle S, Naeije R: Pulmonary vascular effects of dobutamine in experimental pulmonary hypertension. Crit Care Med 2003, 31:1140-1146.

155. Bradford KK, Deb B, Pearl RG: Combination therapy with inhaled nitric oxide and intravenous dobutamine during pulmonary hypertension in the rabbit. J Cardiovasc Pharmacol 2000, 36:146-151.

156. Honerjager P: Pharmacology of bipyridine phosphodiesterase III inhibitors. Am Heart J 1991, 121:1939-1944.

157. Young RA, Ward A: Milrinone. A preliminary review of its pharmacological properties and therapeutic use. Drugs 1988, 36:158-192.

158. Alousi AA, Johnson DC: Pharmacology of the bipyridines: amrinone and milrinone. Circulation 1986, 73:III10-III24.

159. Farah $A E$, Frangakis CJ: Studies on the mechanism of action of the bipyridine milrinone on the heart. Basic Res Cardiol 1989, 84 Suppl 1:85-103.

160. Oztekin I, Yazici S, Oztekin DS, Goksel O, Issever H, Canik S: Effects of lowdose milrinone on weaning from cardiopulmonary bypass and after in patients with mitral stenosis and pulmonary hypertension. Yakugaku Zasshi 2007, 127:375-383.

161. Kihara S, Kawai A, Fukuda T, Yamamoto N, Aomi S, Nishida H, Endo M, Koyanagi $\mathrm{H}$ : Effects of milrinone for right ventricular failure after left ventricular assist device implantation. Heart Vessels 2002, 16:69-71.

162. Fukazawa K, Poliac LC, Pretto EA: Rapid assessment and safe management of severe pulmonary hypertension with milrinone during orthotopic liver transplantation. Clin Transplant 2010, 24:515-519.

163. Harris MN, Daborn AK, O'Dwyer JP: Milrinone and the pulmonary vascular system. Eur J Anaesthesiol Supp/ 1992, 5:27-30.

164. Eichhorn EJ, Konstam MA, Weiland DS, Roberts DJ, Martin TT, Stransky NB, Salem DN: Differential effects of milrinone and dobutamine on right ventricular preload, afterload and systolic performance in congestive heart failure secondary to ischemic or idiopathic dilated cardiomyopathy. Am J Cardiol 1987, 60:1329-1333.

165. Boldt J, Knothe C, Zickmann B, Ballesteros M, Russ W, Dapper F, Hempelmann G: The role of enoximone in cardiac surgery. Br J Anaesth 1992, 69:45-50.

166. Tarr TJ, Jeffrey RR, Kent AP, Cowen ME: Use of enoximone in weaning from cardiopulmonary bypass following mitral valve surgery. Cardiology 1990, 77 Suppl 3:51-57, discussion 62-67.

167. Leeman $M$, Lejeune $P$, Melot C, Naeije R: Reduction in pulmonary hypertension and in airway resistances by enoximone (MDL 17,043) in decompensated COPD. Chest 1987, 91:662-666.

168. Jenkins IR, Dolman J, O'Connor JP, Ansley DM: Amrinone versus dobutamine in cardiac surgical patients with severe pulmonary hypertension after cardiopulmonary bypass: a prospective, randomized double-blinded trial. Anaesth Intensive Care 1997, 25:245-249.

169. Dupuis JY, Bondy R, Cattran C, Nathan HJ, Wynands JE: Amrinone and dobutamine as primary treatment of low cardiac output syndrome following coronary artery surgery: a comparison of their effects on hemodynamics and outcome. J Cardiothorac Vasc Anesth 1992, 6:542-553.

170. Hachenberg T, Mollhoff T, Holst D, Hammel D, Brussel T: Cardiopulmonary effects of enoximone or dobutamine and nitroglycerin on mitral valve regurgitation and pulmonary venous hypertension. J Cardiothorac Vasc Anesth 1997, 11:453-457.

171. Ansell J, Tiarks C, McCue J, Parrilla N, Benotti JR: Amrinone-induced thrombocytopenia. Arch Intern Med 1984, 144:949-952.

172. Boldt J, Knothe C, Zickmann B, Herold C, Dapper E, Hempelmann G: Phosphodiesterase-inhibitors enoximone and piroximone in cardiac surgery: influence on platelet count and function. Intensive Care Med 1992, 18:449-454.
173. Kikura M, Lee MK, Safon RA, Bailey JM, Levy JH: The effects of milrinone on platelets in patients undergoing cardiac surgery. Anesth Analg 1995, 81:44-48.

174. Levy JH, Bailey JM, Deeb GM: Intravenous milrinone in cardiac surgery. Ann Thorac Surg 2002, 73:325-330.

175. Chen EP, Bittner HB, Davis RD Jr, Van Trigt P: Milrinone improves pulmonary hemodynamics and right ventricular function in chronic pulmonary hypertension. Ann Thorac Surg 1997, 63:814-821.

176. Buckley MS, Feldman JP: Nebulized milrinone use in a pulmonary hypertensive crisis. Pharmacotherapy 2007, 27:1763-1766.

177. Wang $H$, Gong M, Zhou B, Dai A: Comparison of inhaled and intravenous milrinone in patients with pulmonary hypertension undergoing mitral valve surgery. Adv Ther 2009, 26:462-468.

178. Haraldssons A, Kieler-Jensen N, Ricksten SE: The additive pulmonary vasodilatory effects of inhaled prostacyclin and inhaled milrinone in postcardiac surgical patients with pulmonary hypertension. Anesth Analg 2001, 93:1439-1445, table of contents.

179. Sablotzki A, Starzmann W, Scheubel R, Grond S, Czeslick EG: Selective pulmonary vasodilation with inhaled aerosolized milrinone in heart transplant candidates. Can J Anaesth 2005, 52:1076-1082.

180. Follath F, Cleland JG, Just H, Papp JG, Scholz H, Peuhkurinen K, Harjola VP, Mitrovic $V$, Abdalla M, Sandell EP, Lehtonen L: Efficacy and safety of intravenous levosimendan compared with dobutamine in severe lowoutput heart failure (the LIDO study): a randomised double-blind trial. Lancet 2002, 360:196-202.

181. Barraud D, Faivre V, Damy T, Welschbillig S, Gayat E, Heymes C, Payen D, Shah AM, Mebazaa A: Levosimendan restores both systolic and diastolic cardiac performance in lipopolysaccharide-treated rabbits: comparison with dobutamine and milrinone. Crit Care Med 2007, 35:1376-1382.

182. Ukkonen H, Saraste M, Akkila J, Knuuti J, Karanko M, lida H, Lehikoinen P, Nagren K, Lehtonen L, Voipio-Pulkki LM: Myocardial efficiency during levosimendan infusion in congestive heart failure. Clin Pharmacol Ther 2000, 68:522-531.

183. Ukkonen H, Saraste M, Akkila J, Knuuti MJ, Lehikoinen P, Nagren K, Lehtonen L, Voipio-Pulkki LM: Myocardial efficiency during calcium sensitization with levosimendan: a noninvasive study with positron emission tomography and echocardiography in healthy volunteers. Clin Pharmacol Ther 1997, 61:596-607.

184. Yildiz O: Vasodilating mechanisms of levosimendan: involvement of $\mathrm{K}+$ channels. J Pharmacol Sci 2007, 104:1-5.

185. Slawsky MT, Colucci WS, Gottlieb SS, Greenberg BH, Haeusslein E, Hare J, Hutchins S, Leier CV, LeJemtel TH, Loh E, Nicklas J, Ogilby D, Singh BN, Smith W: Acute hemodynamic and clinical effects of levosimendan in patients with severe heart failure: study investigators. Circulation 2000, 102:2222-2227.

186. Kivikko M, Antila S, Eha J, Lehtonen L, Pentikainen PJ: Pharmacokinetics of levosimendan and its metabolites during and after a 24-hour continuous infusion in patients with severe heart failure. Int J Clin Pharmacol Ther 2002, 40:465-471.

187. Leather HA, Ver Eycken $K$, Segers $P$, Herijgers $P$, Vandermeersch $E$, Wouters PF: Effects of levosimendan on right ventricular function and ventriculovascular coupling in open chest pigs. Crit Care Med 2003, 31:2339-2343.

188. Kerbaul F, Rondelet B, Demester JP, Fesler P, Huez S, Naeije R, Brimioulle S: Effects of levosimendan versus dobutamine on pressure load-induced right ventricular failure. Crit Care Med 2006, 34:2814-2819.

189. Missant C, Rex S, Segers P, Wouters PF: Levosimendan improves right ventriculovascular coupling in a porcine model of right ventricular dysfunction. Crit Care Med 2007, 35:707-715.

190. Duygu H, Ozerkan F, Zoghi M, Nalbantgil S, Yildiz A, Akilli A, Akin M, Nazli C, Ergene O: Effect of levosimendan on right ventricular systolic and diastolic functions in patients with ischaemic heart failure. Int J Clin Pract 2008, 62:228-233.

191. Russ MA, Prondzinsky R, Carter JM, Schlitt A, Ebelt H, Schmidt H, Lemm H, Heinroth K, Soeffker G, Winkler M, Werdan K, Buerke M: Right ventricular function in myocardial infarction complicated by cardiogenic shock: improvement with levosimendan. Crit Care Med 2009, 37:3017-3023.

192. Yilmaz MB, Yontar C, Erdem A, Karadas F, Yalta K, Turgut OO, Yilmaz A, Tandogan I: Comparative effects of levosimendan and dobutamine on right ventricular function in patients with biventricular heart failure. Heart Vessels 2009, 24:16-21. 
193. Poelzl G, Zwick RH, Grander W, Metzler B, Jonetzko P, Frick M, Ulmer H, Pachinger O, Roithinger FX: Safety and effectiveness of levosimendan in patients with predominant right heart failure. Herz 2008, 33:368-373.

194. Parissis JT, Paraskevaidis I, Bistola V, Farmakis D, Panou F, Kourea K, Nikolaou M, Filippatos G, Kremastinos D: Effects of levosimendan on right ventricular function in patients with advanced heart failure. Am J Cardiol 2006, 98:1489-1492.

195. Morelli A, Teboul JL, Maggiore SM, Vieillard-Baron A, Rocco M, Conti G, De Gaetano A, Picchini U, Orecchioni A, Carbone I, Tritapepe L, Pietropaoli P, Westphal M: Effects of levosimendan on right ventricular afterload in patients with acute respiratory distress syndrome: a pilot study. Crit Care Med 2006, 34:2287-2293.

196. Morais RJ: Levosimendan in severe right ventricular failure following mitral valve replacement. J Cardiothorac Vasc Anesth 2006, 20:82-84.

197. Cicekcioglu F, Parlar Al, Ersoy O, Yay K, Hijazi A, Katircioglu SF: Levosimendan and severe pulmonary hypertension during open heart surgery. Gen Thorac Cardiovasc Surg 2008, 56:563-565.

198. Kleber FX, Bollmann T, Borst MM, Costard-Jackle A, Ewert R, Kivikko M, Petterson T, Pohjanjousi P, Sonntag S, Wikstrom G: Repetitive dosing of intravenous levosimendan improves pulmonary hemodynamics in patients with pulmonary hypertension: results of a pilot study. J Clin Pharmacol 2009, 49:109-115.

199. Raper R: FMM: The heart and circulation in sepsis. Balliere's Clin Anaesthesiol 1990, 4:333-355.

200. Humbert M, Sitbon O, Simonneau G: Treatment of pulmonary arterial hypertension. N Engl J Med 2004, 351:1425-1436.

201. Galie N, Hoeper MM, Humbert M, Torbicki A, Vachiery JL, Barbera JA, Beghetti M, Corris P, Gaine S, Gibbs JS, Gomez-Sanchez MA, Jondeau G, Klepetko W, Opitz C, Peacock A, Rubin L, Zellweger M, Simonneau G: Guidelines for the diagnosis and treatment of pulmonary hypertension: the task force for the diagnosis and treatment of pulmonary hypertension of the European Society of Cardiology (ESC) and the European Respiratory Society (ERS), endorsed by the International Society of Heart and Lung Transplantation (ISHLT). Eur Respir J 2009, 34:1219-1263.

202. Kieler-Jensen N, Lundin S, Ricksten SE: Vasodilator therapy after heart transplantation: effects of inhaled nitric oxide and intravenous prostacyclin, prostaglandin E1, and sodium nitroprusside. J Heart Lung Transplant 1995, 14:436-443.

203. Creagh-Brown BC, Griffiths MJ, Evans TW: Bench-to-bedside review: inhaled nitric oxide therapy in adults. Crit Care 2009, 13:221.

204. McNeil K, Dunning J, Morrell NW: The pulmonary physician in critical care, 13: the pulmonary circulation and right ventricular failure in the ITU. Thorax 2003, 58:157-162.

205. Channick RN, Hoch RC, Newhart JW, Johnson FW, Smith CM: Improvement in pulmonary hypertension and hypoxemia during nitric oxide inhalation in a patient with end-stage pulmonary fibrosis. Am J Respir Crit Care Med 1994, 149:811-814.

206. Griffiths MJ, Evans TW: Inhaled nitric oxide therapy in adults. N Engl I Med 2005, 353:2683-2695

207. Aranda M, Bradford KK, Pearl RG: Combined therapy with inhaled nitric oxide and intravenous vasodilators during acute and chronic experimental pulmonary hypertension. Anesth Analg 1999, 89:152-158.

208. Morgan JM, McCormack DG, Griffiths MJ, Morgan CJ, Barnes PJ, Evans TW: Adenosine as a vasodilator in primary pulmonary hypertension. Circulation 1991, 84:1145-1149.

209. Fullerton DA, Jones SD, Grover FL, McIntyre RC Jr: Adenosine effectively controls pulmonary hypertension after cardiac operations. Ann Thorac Surg 1996, 61:1118-1123, discussion 1123-1114.

210. Haywood GA, Sneddon JF, Bashir Y, Jennison SH, Gray HH, McKenna WJ: Adenosine infusion for the reversal of pulmonary vasoconstriction in biventricular failure: a good test but a poor therapy. Circulation 1992, 86:896-902.

211. Oliveira EC, Ribeiro AL, Amaral CF: Adenosine for vasoreactivity testing in pulmonary hypertension: a head-to-head comparison with inhaled nitric oxide. Respir Med 104:606-611.

212. Pepke-Zaba J, Higenbottam TW, Dinh-Xuan AT, Stone D, Wallwork J: Inhaled nitric oxide as a cause of selective pulmonary vasodilatation in pulmonary hypertension. Lancet 1991, 338:1173-1174.
213. King R, Esmail M, Mahon S, Dingley J, Dwyer S: Use of nitric oxide for decompensated right ventricular failure and circulatory shock after cardiac arrest. Br J Anaesth 2000, 85:628-631.

214. Frostell CG, Blomqvist H, Hedenstierna G, Lundberg J, Zapol WM: Inhaled nitric oxide selectively reverses human hypoxic pulmonary vasoconstriction without causing systemic vasodilation. Anesthesiology 1993, 78:427-435.

215. Schenk $P$, Mittermayer $C$, Ratheiser $K$ : Inhaled nitric oxide in a patient with severe pulmonary embolism. Ann Emerg Med 1999, 33:710-714.

216. Capellier G, Jacques T, Balvay P, Blasco G, Belle E, Barale F: Inhaled nitric oxide in patients with pulmonary embolism. Intensive Care Med 1997, 23:1089-1092.

217. Inglessis I, Shin JT, Lepore JJ, Palacios IF, Zapol WM, Bloch KD, Semigran MJ: Hemodynamic effects of inhaled nitric oxide in right ventricular myocardial infarction and cardiogenic shock. J Am Coll Cardiol 2004, 44:793-798.

218. Fujita Y, Nishida O, Sobue K, Ito H, Kusama N, Inagaki M, Katsuya H: Nitric oxide inhalation is useful in the management of right ventricular failure caused by myocardial infarction. Crit Care Med 2002, 30:1379-1381.

219. Rich GF, Murphy GD Jr, Roos CM, Johns RA: Inhaled nitric oxide: selective pulmonary vasodilation in cardiac surgical patients. Anesthesiology 1993, 78:1028-1035.

220. Macdonald PS, Keogh A, Mundy J, Rogers P, Nicholson A, Harrison G, Jansz $P$, Kaan AM, Spratt P: Adjunctive use of inhaled nitric oxide during implantation of a left ventricular assist device. J Heart Lung Transplant 1998, 17:312-316.

221. Beck JR, Mongero LB, Kroslowitz RM, Choudhri AF, Chen JM, DeRose JJ, Argenziano M, Smerling AJ, Oz MC: Inhaled nitric oxide improves hemodynamics in patients with acute pulmonary hypertension after high-risk cardiac surgery. Perfusion 1999, 14:37-42.

222. Fernandez-Perez ER, Keegan MT, Harrison BA: Inhaled nitric oxide for acute right-ventricular dysfunction after extrapleural pneumonectomy. Respir Care 2006, 51:1172-1176.

223. Fattouch K, Sbraga F, Bianco G, Speziale G, Gucciardo M, Sampognaro R, Ruvolo G: Inhaled prostacyclin, nitric oxide, and nitroprusside in pulmonary hypertension after mitral valve replacement. J Card Surg 2005, 20:171-176.

224. Takaba K, Aota M, Nonaka M, Sugimoto A, Konishi Y: Successful treatment of chronic thromboembolic pulmonary hypertension with inhaled nitric oxide after right ventricular thrombectomy. Jpn I Thorac Cardiovasc Surg 2004, 52:257-260.

225. Maxey TS, Smith CD, Kern JA, Tribble CG, Jones DR, Kron IL, Crosby IK: Beneficial effects of inhaled nitric oxide in adult cardiac surgical patients. Ann Thorac Surg 2002, 73:529-532, discussion 532-523.

226. Khan TA, Schnickel G, Ross D, Bastani S, Laks H, Esmailian F, Marelli D, Beygui R, Shemin R, Watson L, Vartapetian I, Ardehali A: A prospective, randomized, crossover pilot study of inhaled nitric oxide versus inhaled prostacyclin in heart transplant and lung transplant recipients. J Thorac Cardiovasc Surg 2009, 138:1417-1424.

227. Carrier M, Blaise G, Belisle S, Perrault LP, Pellerin M, Petitclerc R, Pelletier LC: Nitric oxide inhalation in the treatment of primary graft failure following heart transplantation. J Heart Lung Transplant 1999, 18:664-667.

228. Trummer G, Berchtold-Herz M, Martin J, Beyersdorf F: Successful treatment of pulmonary hypertension with inhaled nitric oxide after pulmonary embolectomy. Ann Thorac Surg 2002, 73:1299-1301.

229. Yoshikawa T, Date H, Yamashita M, Nagahiro I, Aoe M, Shimizu N: Inhaled nitric oxide ameliorates postoperative acute graft dysfunction after living-donor lobar lung transplantation. Jpn J Thorac Cardiovasc Surg 2000, 48:742-745.

230. Girardis M, Pasqualotto A, Colo F, Dal Pos L, Sabbadini D, Pasqualucci A, Pasetto A: Severe hypoxemia and pulmonary hypertension during orthotopic liver transplantation: a successful use of inhaled nitric oxide. Intensive Care Med 1999, 25:638.

231. Ralley FE: The use of nitric oxide for managing catastrophic pulmonary vasoconstriction arising from protamine administration. Anesth Analg 1999, 88:505-507.

232. Williams TJ, Salamonsen RF, Snell G, Kaye D, Esmore DS: Preliminary experience with inhaled nitric oxide for acute pulmonary hypertension after heart transplantation. J Heart Lung Transplant 1995, 14:419-423.

233. Molmenti EP, Ramsay M, Ramsay K, Lynch K, Tillmann Hein HA, Molmenti H, Levy M, Goldstein R, Ausloos K, East C, Fasola C, Jung G, Escobar J, 
Klintmalm G: Epoprostenol and nitric oxide therapy for severe pulmonary hypertension in liver transplantation. Transplant Proc 2001, 33:1332.

234. Snow DJ, Gray SJ, Ghosh S, Foubert L, Oduro A, Higenbottam TW, Wells FC, Latimer RD: Inhaled nitric oxide in patients with normal and increased pulmonary vascular resistance after cardiac surgery. Br J Anaesth 1994, 72:185-189.

235. Bender KA, Alexander JA, Enos JM, Skimming JW: Effects of inhaled nitric oxide in patients with hypoxemia and pulmonary hypertension after cardiac surgery. Am J Crit Care 1997, 6:127-131.

236. Solina A, Papp D, Ginsberg S, Krause T, Grubb W, Scholz P, Pena LL, Cody R A comparison of inhaled nitric oxide and milrinone for the treatment of pulmonary hypertension in adult cardiac surgery patients. J Cardiothorac Vasc Anesth 2000, 14:12-17.

237. Solina AR, Ginsberg SH, Papp D, Pantin EJ, Denny J, Ghandivel I, Krause TJ: Response to nitric oxide during adult cardiac surgery. J Invest Surg 2002, 15:5-14

238. Solina AR, Ginsberg SH, Papp D, Grubb WR, Scholz PM, Pantin EJ, Cody RP, Krause $\mathrm{TJ}$ : Dose response to nitric oxide in adult cardiac surgery patients. J Clin Anesth 2001, 13:281-286.

239. Fattouch K, Sbraga F, Sampognaro R, Bianco G, Gucciardo M, Lavalle C, Vizza CD, Fedele F, Ruvolo G: Treatment of pulmonary hypertension in patients undergoing cardiac surgery with cardiopulmonary bypass: a randomized, prospective, double-blind study. J Cardiovasc Med (Hagerstown) 2006, 7:119-123.

240. Healy DG, Veerasingam D, McHale J, Luke D: Successful perioperative utilisation of inhaled nitric oxide in mitral valve surgery. J Cardiovasc Surg (Torino) 2006, 47:217-220.

241. Rossaint R, Falke KJ, Lopez F, Slama K, Pison U, Zapol WM: Inhaled nitric oxide for the adult respiratory distress syndrome. N Engl J Med 1993, 328:399-405.

242. Fierobe L, Brunet F, Dhainaut JF, Monchi M, Belghith M, Mira JP, Dall'avaSantucci J, Dinh-Xuan AT: Effect of inhaled nitric oxide on right ventricular function in adult respiratory distress syndrome. Am J Respir Crit Care Med 1995, 151:1414-1419.

243. Romberg-Camps MJ, Korsten HH, Botman CJ, Bindels AJ, Roos AN: Right ventricular failure in acute respiratory distress syndrome. Neth J Med 2000, 57:94-97.

244. Chiche JD, Canivet JL, Damas P, Joris J, Lamy M: Inhaled nitric oxide for hemodynamic support after postpneumonectomy ARDS. Intensive Care Med 1995, 21:675-678.

245. Benzing A, Mols G, Beyer U, Geiger K: Large increase in cardiac output in a patient with ARDS and acute right heart failure during inhalation of nitric oxide. Acta Anaesthesiol Scand 1997, 41:643-646.

246. Bigatello LM, Hurford WE, Kacmarek RM, Roberts JD Jr, Zapol WM: Prolonged inhalation of low concentrations of nitric oxide in patients with severe adult respiratory distress syndrome: effects on pulmonary hemodynamics and oxygenation. Anesthesiology 1994, 80:761-770.

247. Hsu CW, Lee DL, Lin SL, Sun SF, Chang HW: The initial response to inhaled nitric oxide treatment for intensive care unit patients with acute respiratory distress syndrome. Respiration 2008, 75:288-295.

248. Gerlach H, Keh D, Semmerow A, Busch T, Lewandowski K, Pappert DM, Rossaint R, Falke KJ: Dose-response characteristics during long-term inhalation of nitric oxide in patients with severe acute respiratory distress syndrome: a prospective, randomized, controlled study. Am J Respir Crit Care Med 2003, 167:1008-1015.

249. Dellinger RP, Zimmerman JL, Taylor RW, Straube RC, Hauser DL, Criner GJ, Davis K Jr, Hyers TM, Papadakos P: Effects of inhaled nitric oxide in patients with acute respiratory distress syndrome: results of a randomized phase II trial: inhaled nitric oxide in ARDS study group. Crit Care Med 1998, 26:15-23.

250. Taylor RW, Zimmerman JL, Dellinger RP, Straube RC, Criner GJ, Davis K Jr, Kelly KM, Smith TC, Small RJ: Low-dose inhaled nitric oxide in patients with acute lung injury: a randomized controlled trial. JAMA 2004, 291:1603-1609.

251. Brett SJ, Hansell DM, Evans TW: Clinical correlates in acute lung injury: response to inhaled nitric oxide. Chest 1998, 114:1397-1404

252. Manktelow C, Bigatello LM, Hess D, Hurford WE: Physiologic determinants of the response to inhaled nitric oxide in patients with acute respiratory distress syndrome. Anesthesiology 1997, 87:297-307.
253. Adhikari NK, Burns KE, Friedrich JO, Granton JT, Cook DJ, Meade MO: Effect of nitric oxide on oxygenation and mortality in acute lung injury: systematic review and meta-analysis. BMJ 2007, 334:779.

254. Sokol J, Jacobs SE, Bohn D: Inhaled nitric oxide for acute hypoxic respiratory failure in children and adults: a meta-analysis. Anesth Analg 2003, 97:989-998.

255. Troncy E, Collet JP, Shapiro S, Guimond JG, Blair L, Ducruet T, Francoeur M, Charbonneau M, Blaise G: Inhaled nitric oxide in acute respiratory distress syndrome: a pilot randomized controlled study. Am J Respir Crit Care Med 1998, 157:1483-1488.

256. Michael JR, Barton RG, Saffle JR, Mone M, Markewitz BA, Hillier K, Elstad MR, Campbell EJ, Troyer BE, Whatley RE, Liou TG, Samuelson WM, Carveth HJ, Hinson DM, Morris SE, Davis BL, Day RW: Inhaled nitric oxide versus conventional therapy: effect on oxygenation in ARDS. Am J Respir Crit Care Med 1998, 157:1372-1380.

257. Lundin S, Mang H, Smithies M, Stenqvist O, Frostell C: Inhalation of nitric oxide in acute lung injury: results of a European multicentre study: the European Study Group of Inhaled Nitric Oxide. Intensive Care Med 1999, 25:911-919.

258. Vater Y, Martay K, Dembo G, Bowdle TA, Weinbroum AA: Intraoperative epoprostenol and nitric oxide for severe pulmonary hypertension during orthotopic liver transplantation: a case report and review of the literature. Med Sci Monit 2006, 12:CS115-CS118.

259. Flondor M, Merkel M, Hofstetter C, Irlbeck M, Frey L, Zwissler B: The effect of inhaled nitric oxide and inhaled iloprost on hypoxaemia in a patient with pulmonary hypertension after pulmonary thrombarterectomy. Anaesthesia 2006, 61:1200-1203.

260. Lepore JJ, Maroo A, Bigatello LM, Dec GW, Zapol WM, Bloch KD, Semigran MJ: Hemodynamic effects of sildenafil in patients with congestive heart failure and pulmonary hypertension: combined administration with inhaled nitric oxide. Chest 2005, 127:1647-1653.

261. Lepore JJ, Maroo A, Pereira NL, Ginns LC, Dec GW, Zapol WM, Bloch KD, Semigran MJ: Effect of sildenafil on the acute pulmonary vasodilator response to inhaled nitric oxide in adults with primary pulmonary hypertension. Am J Cardiol 2002, 90:677-680.

262. Lavoie A, Hall JB, Olson DM, Wylam ME: Life-threatening effects of discontinuing inhaled nitric oxide in severe respiratory failure. Am $J$ Respir Crit Care Med 1996, 153:1985-1987.

263. Atz AM, Adatia I, Wessel DL: Rebound pulmonary hypertension after inhalation of nitric oxide. Ann Thorac Surg 1996, 62:1759-1764.

264. Christenson J, Lavoie A, O'Connor M, Bhorade S, Pohlman A, Hall JB: The incidence and pathogenesis of cardiopulmonary deterioration after abrupt withdrawal of inhaled nitric oxide. Am J Respir Crit Care Med 2000, 161:1443-1449.

265. Giacomini M, Borotto E, Bosotti L, Denkewitz T, Reali-Forster C, Carlucci $P$, Centanni S, Mantero A, lapichino G: Vardenafil and weaning from inhaled nitric oxide: effect on pulmonary hypertension in ARDS. Anaesth Intensive Care 2007, 35:91-93.

266. Trachte AL, Lobato EB, Urdaneta F, Hess PJ, Klodell CT, Martin TD, Staples ED, Beaver TM: Oral sildenafil reduces pulmonary hypertension after cardiac surgery. Ann Thorac Surg 2005, 79:194-197, discussion 194197.

267. Atz AM, Wessel DL: Sildenafil ameliorates effects of inhaled nitric oxide withdrawal. Anesthesiology 1999, 91:307-310.

268. Namachivayam P, Theilen U, Butt WW, Cooper SM, Penny DJ, Shekerdemian LS: Sildenafil prevents rebound pulmonary hypertension after withdrawal of nitric oxide in children. Am J Respir Crit Care Med 2006, 174:1042-1047.

269. Klodell CT Jr, Morey TE, Lobato EB, Aranda JM Jr, Staples ED, Schofield RS, Hess PJ, Martin TD, Beaver TM: Effect of sildenafil on pulmonary artery pressure, systemic pressure, and nitric oxide utilization in patients with left ventricular assist devices. Ann Thorac Surg 2007, 83:68-71, discussion 71.

270. Mychaskiw G, Sachdev V, Heath BJ: Sildenafil (Viagra) facilitates weaning of inhaled nitric oxide following placement of a biventricular-assist device. J Clin Anesth 2001, 13:218-220.

271. Moncada S, Gryglewski RJ, Bunting S, Vane JR: A lipid peroxide inhibits the enzyme in blood vessel microsomes that generates from prostaglandin endoperoxides the substance (prostaglandin $\mathrm{X}$ ) which prevents platelet aggregation. Prostaglandins 1976, 12:715-737. 
272. Clapp $L H$, Finney P, Turcato S, Tran S, Rubin $L$, Tinker A: Differential effects of stable prostacyclin analogs on smooth muscle proliferation and cyclic AMP generation in human pulmonary artery. Am J Respir Cell Mol Biol 2002, 26:194-201.

273. Rubin LJ, Mendoza J, Hood M, McGoon M, Barst R, Williams WB, Diehl JH, Crow J, Long W: Treatment of primary pulmonary hypertension with continuous intravenous prostacyclin (epoprostenol): results of a randomized trial. Ann Intern Med 1990, 112:485-491.

274. Barst RJ, Rubin LJ, Long WA, McGoon MD, Rich S, Badesch DB, Groves BM, Tapson VF, Bourge RC, Brundage BH, Koerner SK, Langleben D, Keller CA, Murali S, Uretsky BF, Clayton LM, Jobsis MM, Blackburn DS, Shortino D, Crow JW: A comparison of continuous intravenous epoprostenol (prostacyclin) with conventional therapy for primary pulmonary hypertension: the Primary Pulmonary Hypertension Study Group. N Engl J Med 1996, 334:296-302.

275. Olschewski H, Simonneau G, Galie N, Higenbottam T, Naeije R, Rubin LJ, Nikkho S, Speich R, Hoeper MM, Behr J, Winkler J, Sitbon O, Popov W, Ghofrani HA, Manes A, Kiely DG, Ewert R, Meyer A, Corris PA, Delcroix M, Gomez-Sanchez M, Siedentop H, Seeger W: Inhaled iloprost for severe pulmonary hypertension. N Engl J Med 2002, 347:322-329.

276. Hoeper MM, Schwarze M, Ehlerding S, Adler-Schuermeyer A, Spiekerkoetter E, Niedermeyer J, Hamm M, Fabel H: Long-term treatment of primary pulmonary hypertension with aerosolized iloprost, a prostacyclin analogue. N Engl J Med 2000, 342:1866-1870.

277. Hoeper MM, Olschewski H, Ghofrani HA, Wilkens H, Winkler J, Borst MM, Niedermeyer J, Fabel H, Seeger W: A comparison of the acute hemodynamic effects of inhaled nitric oxide and aerosolized iloprost in primary pulmonary hypertension: German PPH study group. J Am Coll Cardiol 2000, 35:176-182

278. Olschewski H, Ghofrani HA, Walmrath D, Temmesfeld-Wollbruck B, Grimminger $F$, Seeger W: Recovery from circulatory shock in severe primary pulmonary hypertension (PPH) with aerosolization of iloprost. Intensive Care Med 1998, 24:631-634.

279. Sitbon O, Humbert M, Nunes H, Parent F, Garcia G, Herve P, Rainisio M, Simonneau G: Long-term intravenous epoprostenol infusion in primary pulmonary hypertension: prognostic factors and survival. J Am Coll Cardiol 2002, 40:780-788.

280. Kieler-Jensen N, Milocco I, Ricksten SE: Pulmonary vasodilation after heart transplantation: a comparison among prostacyclin, sodium nitroprusside, and nitroglycerin on right ventricular function and pulmonary selectivity. J Heart Lung Transplant 1993, 12:179-184.

281. D'Ambra MN, LaRaia PJ, Philbin DM, Watkins WD, Hilgenberg AD, Buckley MJ: Prostaglandin E1: a new therapy for refractory right heart failure and pulmonary hypertension after mitral valve replacement. J Thorac Cardiovasc Surg 1985, 89:567-572.

282. Vincent JL, Carlier E, Pinsky MR, Goldstein J, Naeije R, Lejeune P, Brimioulle S, Leclerc JL, Kahn RJ, Primo G: Prostaglandin E1 infusion for right ventricular failure after cardiac transplantation. J Thorac Cardiovasc Surg 1992, 103:33-39.

283. Radovancevic B, Vrtovec B, Thomas CD, Croitoru M, Myers TJ, Radovancevic R, Khan T, Massin EK, Frazier OH: Nitric oxide versus prostaglandin E1 for reduction of pulmonary hypertension in heart transplant candidates. J Heart Lung Transplant 2005, 24:690-695.

284. Schmid ER, Burki C, Engel MH, Schmidlin D, Tornic M, Seifert B Inhaled nitric oxide versus intravenous vasodilators in severe pulmonary hypertension after cardiac surgery. Anesth Analg 1999, 89:1108-1115

285. Elliott CG, Palevsky HI: Treatment with epoprostenol of pulmonary arterial hypertension following mitral valve replacement for mitral stenosis. Thorax 2004, 59:536-537.

286. Haraldsson A, Kieler-Jensen N, Ricksten SE: Inhaled prostacyclin for treatment of pulmonary hypertension after cardiac surgery or heart transplantation: a pharmacodynamic study. J Cardiothorac Vasc Anesth 1996, 10:864-868.

287. Hache M, Denault AY, Belisle S, Couture P, Babin D, Tetrault F, Guimond JG: Inhaled prostacyclin (PGI2) is an effective addition to the treatment of pulmonary hypertension and hypoxia in the operating room and intensive care unit. Can J Anaesth 2001, 48:924-929.

288. De Wet CJ, Affleck DG, Jacobsohn E, Avidan MS, Tymkew H, Hill LL, Zanaboni PB, Moazami N, Smith JR: Inhaled prostacyclin is safe, effective, and affordable in patients with pulmonary hypertension, right heart dysfunction, and refractory hypoxemia after cardiothoracic surgery. $J$ Thorac Cardiovasc Surg 2004, 127:1058-1067.

289. Schroeder RA, Wood GL, Plotkin JS, Kuo PC: Intraoperative use of inhaled PGI(2) for acute pulmonary hypertension and right ventricular failure. Anesth Analg 2000, 91:291-295.

290. Lowson SM, Doctor A, Walsh BK, Doorley PA: Inhaled prostacyclin for the treatment of pulmonary hypertension after cardiac surgery. Crit Care Med 2002, 30:2762-2764.

291. Kramm T, Eberle B, Guth S, Mayer E: Inhaled iloprost to control residual pulmonary hypertension following pulmonary endarterectomy. Eur J Cardiothorac Surg 2005, 28:882-888.

292. Rex S, Schaelte G, Metzelder S, Flier S, de Waal EE, Autschbach R, Rossaint R, Buhre W: Inhaled iloprost to control pulmonary artery hypertension in patients undergoing mitral valve surgery: a prospective, randomizedcontrolled trial. Acta Anaesthesiol Scand 2008, 52:65-72.

293. Yurtseven N, Karaca P, Uysal G, Ozkul V, Cimen S, Tuygun AK, Yuksek A, Canik S: A comparison of the acute hemodynamic effects of inhaled nitroglycerin and iloprost in patients with pulmonary hypertension undergoing mitral valve surgery. Ann Thorac Cardiovasc Surg 2006, 12:319-323.

294. Baysal A, Bilsel S, Bulbul OG, Kayacioglu I, Idiz M, Yekeler I: Comparison of the usage of intravenous iloprost and nitroglycerin for pulmonary hypertension during valvular heart surgery. Heart Surg Forum 2006, 9: E536-E542.

295. Tissieres P, Nicod L, Barazzone-Argiroffo C, Rimensberger PC, Beghetti M: Aerosolized iloprost as a bridge to lung transplantation in a patient with cystic fibrosis and pulmonary hypertension. Ann Thorac Surg 2004, 78 e48-50.

296. Sablotzki A, Hentschel T, Gruenig E, Schubert S, Friedrich I, Muhling J, Dehne MG, Czeslick E: Hemodynamic effects of inhaled aerosolized iloprost and inhaled nitric oxide in heart transplant candidates with elevated pulmonary vascular resistance. Eur J Cardiothorac Surg 2002, 22:746-752.

297. Theodoraki K, Rellia P, Thanopoulos A, Tsourelis L, Zarkalis D, Sfyrakis P, Antoniou T: Inhaled iloprost controls pulmonary hypertension after cardiopulmonary bypass. Can J Anaesth 2002, 49:963-967.

298. Winterhalter M, Simon A, Fischer S, Rahe-Meyer N, Chamtzidou N, Hecker H, Zuk J, Piepenbrock S, Struber M: Comparison of inhaled iloprost and nitric oxide in patients with pulmonary hypertension during weaning from cardiopulmonary bypass in cardiac surgery: a prospective randomized trial. J Cardiothorac Vasc Anesth 2008, 22:406-413.

299. Webb SA, Stott S, van Heerden PV: The use of inhaled aerosolized prostacyclin (IAP) in the treatment of pulmonary hypertension secondary to pulmonary embolism. Intensive Care Med 1996, 22:353-355.

300. Haraldsson A, Kieler-Jensen N, Wadenvik H, Ricksten SE: Inhaled prostacyclin and platelet function after cardiac surgery and cardiopulmonary bypass. Intensive Care Med 2000, 26:188-194.

301. Radermacher P, Santak B, Wust HJ, Tarnow J, Falke KJ: Prostacyclin and right ventricular function in patients with pulmonary hypertension associated with ARDS. Intensive Care Med 1990, 16:227-232.

302. Zwissler B, Kemming G, Habler O, Kleen M, Merkel M, Haller M, Briegel J, Welte M, Peter K: Inhaled prostacyclin (PGI2) versus inhaled nitric oxide in adult respiratory distress syndrome. Am J Respir Crit Care Med 1996, 154:1671-1677.

303. van Heerden PV, Barden A, Michalopoulos N, Bulsara MK, Roberts BL: Doseresponse to inhaled aerosolized prostacyclin for hypoxemia due to ARDS. Chest 2000, 117:819-827.

304. Walmrath D, Schneider T, Pilch J, Grimminger F, Seeger W: Aerosolised prostacyclin in adult respiratory distress syndrome. Lancet 1993, 342:961-962.

305. Van Heerden PV, Webb SA, Hee G, Corkeron M, Thompson WR: Inhaled aerosolized prostacyclin as a selective pulmonary vasodilator for the treatment of severe hypoxaemia. Anaesth Intensive Care 1996, 24:87-90.

306. Meyer J, Theilmeier G, Van Aken H, Bone HG, Busse H, Waurick R, Hinder F, Booke M: Inhaled prostaglandin E1 for treatment of acute lung injury in severe multiple organ failure. Anesth Analg 1998, 86:753-758.

307. Kuhlen R, Walbert E, Frankel P, Thaden S, Behrendt W, Rossaint R: Combination of inhaled nitric oxide and intravenous prostacyclin for successful treatment of severe pulmonary hypertension in a patient with acute respiratory distress syndrome. Intensive Care Med 1999, 25:752-754. 
308. Prasad S, Wilkinson J, Gatzoulis MA: Sildenafil in primary pulmonary hypertension. N Engl J Med 2000, 343:1342.

309. Preston IR, Klinger JR, Houtches J, Nelson D, Farber HW, Hill NS: Acute and chronic effects of sildenafil in patients with pulmonary arterial hypertension. Respir Med 2005, 99:1501-1510.

310. Michelakis E, Tymchak W, Lien D, Webster L, Hashimoto K, Archer S: Oral sildenafil is an effective and specific pulmonary vasodilator in patients with pulmonary arterial hypertension: comparison with inhaled nitric oxide. Circulation 2002, 105:2398-2403.

311. Archer SL, Michelakis ED: Phosphodiesterase type 5 inhibitors for pulmonary arterial hypertension. N Engl J Med 2009, 361:1864-1871.

312. Giaid A, Saleh D: Reduced expression of endothelial nitric oxide synthase in the lungs of patients with pulmonary hypertension. N Engl J Med 1995, 333:214-221.

313. Black SM, Sanchez LS, Mata-Greenwood E, Bekker JM, Steinhorn RH, Fineman JR: SGC and PDE5 are elevated in lambs with increased pulmonary blood flow and pulmonary hypertension. Am J Physiol Lung Cell Mol Physiol 2001, 281:L1051-L1057.

314. Wharton J, Strange JW, Moller GM, Growcott EJ, Ren X, Franklyn AP, Phillips SC, Wilkins MR: Antiproliferative effects of phosphodiesterase type 5 inhibition in human pulmonary artery cells. Am J Respir Crit Care Med 2005, 172:105-113.

315. Nagendran J, Archer SL, Soliman D, Gurtu V, Moudgil R, Haromy A, St Aubin C, Webster L, Rebeyka IM, Ross DB, Light PE, Dyck JR, Michelakis ED: Phosphodiesterase type 5 is highly expressed in the hypertrophied human right ventricle, and acute inhibition of phosphodiesterase type 5 improves contractility. Circulation 2007, 116:238-248.

316. Packer M: Vasodilator therapy for primary pulmonary hypertension: limitations and hazards. Ann Intern Med 1985, 103:258-270

317. De Santo LS, Mastroianni C, Romano G, Amarelli C, Marra C, Maiello C, Galdieri N, Della Corte A, Cotrufo M, Caianiello G: Role of sildenafil in acute posttransplant right ventricular dysfunction: successful experience in 13 consecutive patients. Transplant Proc 2008, 40:2015-2018.

318. Shim JK, Choi YS, Oh YJ, Kim DH, Hong YW, Kwak YL: Effect of oral sildenafil citrate on intraoperative hemodynamics in patients with pulmonary hypertension undergoing valvular heart surgery. J Thorac Cardiovasc Surg 2006, 132:1420-1425.

319. Madden BP, Sheth A, Ho TB, Park JE, Kanagasabay RR: Potential role for sildenafil in the management of perioperative pulmonary hypertension and right ventricular dysfunction after cardiac surgery. Br J Anaesth 2004, 93:155-156.

320. Fung E, Fiscus RR, Yim AP, Angelini GD, Arifi AA: The potential use of type5 phosphodiesterase inhibitors in coronary artery bypass graft surgery. Chest 2005, 128:3065-3073.

321. Aubin MC, Laurendeau S, Mommerot A, Lamarche Y, Denault A, Carrier M, Perrault LP: Differential effects of inhaled and intravenous sildenafil in the prevention of the pulmonary endothelial dysfunction due to cardiopulmonary bypass. J Cardiovasc Pharmacol 2008, 51:11-17.

322. Ghofrani HA, Wiedemann R, Rose F, Schermuly RT, Olschewski H, Weissmann N, Gunther A, Walmrath D, Seeger W, Grimminger F: Sildenafil for treatment of lung fibrosis and pulmonary hypertension: a randomised controlled trial. Lancet 2002, 360:895-900.

323. Ng J, Finney SJ, Shulman R, Bellingan GJ, Singer M, Glynne PA: Treatment of pulmonary hypertension in the general adult intensive care unit: a role for oral sildenafil? Br J Anaesth 2005, 94:774-777.

324. Cornet AD, Hofstra JJ, Swart EL, Girbes AR, Juffermans NP: Sildenafil attenuates pulmonary arterial pressure but does not improve oxygenation during ARDS. Intensive Care Med 2010, 36:758-764.

325. Botha P, Parry G, Dark JH, Macgowan GA: Acute hemodynamic effects of intravenous sildenafil citrate in congestive heart failure: comparison of phosphodiesterase type-3 and -5 inhibition. J Heart Lung Transplant 2009, 28:676-682.

326. Moudgil R, Michelakis ED, Archer SL: Hypoxic pulmonary vasoconstriction. J Appl Physiol 2005, 98:390-403.

327. Lejeune P, Brimioulle S, Leeman M, Hallemans R, Melot C, Naeije R: Enhancement of hypoxic pulmonary vasoconstriction by metabolic acidosis in dogs. Anesthesiology 1990, 73:256-264.

328. Balanos GM, Talbot NP, Dorrington KL, Robbins PA: Human pulmonary vascular response to $4 \mathrm{~h}$ of hypercapnia and hypocapnia measured using Doppler echocardiography. J Appl Physiol 2003, 94:1543-1551.
329. Mekontso Dessap A, Charron C, Devaquet J, Aboab J, Jardin F, Brochard L, Vieillard-Baron A: Impact of acute hypercapnia and augmented positive end-expiratory pressure on right ventricle function in severe acute respiratory distress syndrome. Intensive Care Med 2009, 35:1850-1858.

330. Puybasset L, Stewart T, Rouby JJ, Cluzel P, Mourgeon E, Belin MF, Arthaud M, Landault C, Viars P: Inhaled nitric oxide reverses the increase in pulmonary vascular resistance induced by permissive hypercapnia in patients with acute respiratory distress syndrome. Anesthesiology 1994, 80:1254-1267.

331. Biondi JW, Schulman DS, Matthay RA: Effects of mechanical ventilation on right and left ventricular function. Clin Chest Med 1988, 9:55-71.

332. Jardin F, Gueret P, Dubourg O, Farcot JC, Margairaz A, Bourdarias JP: Twodimensional echocardiographic evaluation of right ventricular size and contractility in acute respiratory failure. Crit Care Med 1985, 13:952-956.

333. Jardin F, Vieillard-Baron A: Is there a safe plateau pressure in ARDS? The right heart only knows. Intensive Care Med 2007, 33:444-447.

334. Vieillard-Baron A, Rabiller A, Chergui K, Peyrouset O, Page B, Beauchet A, Jardin F: Prone position improves mechanics and alveolar ventilation in acute respiratory distress syndrome. Intensive Care Med 2005, 31:220-226.

335. David M, von Bardeleben RS, Weiler N, Markstaller K, Scholz A, Karmrodt J, Eberle B: Cardiac function and haemodynamics during transition to highfrequency oscillatory ventilation. Eur J Anaesthesiol 2004, 21:944-952.

336. Gernoth C, Wagner G, Pelosi P, Luecke T: Respiratory and haemodynamic changes during decremental open lung positive end-expiratory pressure titration in patients with acute respiratory distress syndrome. Crit Care 2009, 13:R59.

337. Shekerdemian LS, Shore DF, Lincoln C, Bush A, Redington AN: Negativepressure ventilation improves cardiac output after right heart surgery. Circulation 1996, 94:1149-1155.

338. Shekerdemian LS, Bush A, Shore DF, Lincoln C, Redington AN: Cardiopulmonary interactions after Fontan operations: augmentation of cardiac output using negative pressure ventilation. Circulation 1997, 96:3934-3942.

339. Giesler GM, Gomez JS, Letsou G, Vooletich M, Smalling RW: Initial report of percutaneous right ventricular assist for right ventricular shock secondary to right ventricular infarction. Catheter Cardiovasc Interv 2006, 68:263-266.

340. Fonger JD, Borkon AM, Baumgartner WA, Achuff SC, Augustine S, Reitz BA: Acute right ventricular failure following heart transplantation: improvement with prostaglandin E1 and right ventricular assist. J Heart Transplant 1986, 5:317-321.

341. Nagarsheth NP, Pinney S, Bassily-Marcus A, Anyanwu A, Friedman L, Beilin Y: Successful placement of a right ventricular assist device for treatment of a presumed amniotic fluid embolism. Anesth Analg 2008, 107:962-964.

342. Berman M, Tsui S, Vuylsteke A, Klein A, Jenkins DP: Life-threatening right ventricular failure in pulmonary hypertension: RVAD or ECMO? J Heart Lung Transplant 2008, 27:1188-1189.

343. Keogh AM, Mayer E, Benza RL, Corris P, Dartevelle PG, Frost AE, Kim NH, Lang IM, Pepke-Zaba J, Sandoval J: Interventional and surgical modalities of treatment in pulmonary hypertension. J Am Coll Cardiol 2009, 54: S67-S77.

344. Strueber M, Hoeper MM, Fischer S, Cypel M, Warnecke G, Gottlieb J, Pierre A, Welte T, Haverich A, Simon AR, Keshavjee S: Bridge to thoracic organ transplantation in patients with pulmonary arterial hypertension using a pumpless lung assist device. Am J Transplant 2009, 9:853-857.

345. Felton TW, McCormick BA, Finfer SR, Fisher MM: Life-threatening pulmonary hypertension and right ventricular failure complicating calcium and phosphate replacement in the intensive care unit. Anaesthesia 2006, 61:49-53.

346. Satoh H, Masuda Y, Izuta S, Yaku H, Obara H: Pregnant patient with primary pulmonary hypertension: general anesthesia and extracorporeal membrane oxygenation support for termination of pregnancy. Anesthesiology 2002, 97:1638-1640.

347. Chan CY, Chen YS, Ko WJ, Wang SS, Chiu IS, Lee YC, Chu SH: Extracorporeal membrane oxygenation support for single lung transplantation in a patient with primary pulmonary hypertension. $J$ Heart Lung Transplant 1998, 17:325-327.

348. Jones RL, St Cyr JA, Tornabene SP, Lauber B, Harken AH: Reversible pulmonary hypertension secondary to mitral valvular disease as an 
indication for extracorporeal membrane oxygenation. I Cardiothorac Vasc Anesth 1991, 5:494-497.

349. Gregoric ID, Chandra D, Myers TJ, Scheinin SA, Loyalka P, Kar B: Extracorporeal membrane oxygenation as a bridge to emergency heartlung transplantation in a patient with idiopathic pulmonary arterial hypertension. J Heart Lung Transplant 2008, 27:466-468.

350. Hsu HH, Ko WJ, Chen JS, Lin CH, Kuo SW, Huang SC, Lee YC: Extracorporeal membrane oxygenation in pulmonary crisis and primary graft dysfunction. J Heart Lung Transplant 2008, 27:233-237.

351. Berman M, Tsui S, Vuylsteke A, Snell A, Colah S, Latimer R, Hall R, Arrowsmith JE, Kneeshaw J, Klein AA, Jenkins DP: Successful extracorporeal membrane oxygenation support after pulmonary thromboendarterectomy. Ann Thorac Surg 2008, 86:1261-1267.

352. Deehring R, Kiss AB, Garrett A, Hillier AG: Extracorporeal membrane oxygenation as a bridge to surgical embolectomy in acute fulminant pulmonary embolism. Am J Emerg Med 2006, 24:879-880.

353. Haller I, Kofler A, Lederer W, Chemelli A, Wiedermann FJ: Acute pulmonary artery embolism during transcatheter embolization: successful resuscitation with veno-arterial extracorporeal membrane oxygenation. Anesth Analg 2008, 107:945-947.

354. Szocik J, Rudich S, Csete M: ECMO resuscitation after massive pulmonary embolism during liver transplantation. Anesthesiology 2002, 97:763-764.

355. Arlt M, Philipp A, lesalnieks I, Kobuch R, Graf BM: Successful use of a new hand-held ECMO system in cardiopulmonary failure and bleeding shock after thrombolysis in massive post-partal pulmonary embolism. Perfusion 2009, 24:49-50.

356. Gold JP, Shemin RJ, DiSesa VJ, Cohn L, Collins JJ Jr: Balloon pump support of the failing right heart. Clin Cardiol 1985, 8:599-602.

357. Arafa OE, Geiran OR, Andersen K, Fosse E, Simonsen S, Svennevig JL: Intraaortic balloon pumping for predominantly right ventricular failure after heart transplantation. Ann Thorac Surg 2000, 70:1587-1593.

358. Darrah WC, Sharpe MD, Guiraudon GM, Neal A: Intraaortic balloon counterpulsation improves right ventricular failure resulting from pressure overload. Ann Thorac Surg 1997, 64:1718-1723, discussion 17231714.

359. Rothman A, Sklansky MS, Lucas WW, Kashani IA, Shaughnessy RD, Channick RN, Auger WR, Fedullo PF, Smith CM, Kriett JM, Jamieson SW: Atrial septostomy as a bridge to lung transplantation in patients with severe pulmonary hypertension. Am J Cardiol 1999, 84:682-686.

360. Rich S, Dodin E, McLaughlin W: Usefulness of atrial septostomy as a treatment for primary pulmonary hypertension and guidelines for its application. Am J Cardiol 1997, 80:369-371.

361. Druml W, Steltzer H, Waldhausl W, Lenz K, Hammerle A, Vierhapper $H$, Gasic S, Wagner OF: Endothelin-1 in adult respiratory distress syndrome. Am Rev Respir Dis 1993, 148:1169-1173.

362. Lambermont B, Ghuysen A, Kolh P, Tchana-Sato V, Segers P, Gerard P, Morimont $P$, Magis D, Dogne JM, Masereel B, D'Orio V: Effects of endotoxic shock on right ventricular systolic function and mechanical efficiency. Cardiovasc Res 2003, 59:412-418.

363. Nuckton TJ, Alonso JA, Kallet RH, Daniel BM, Pittet JF, Eisner MD, Matthay MA: Pulmonary dead-space fraction as a risk factor for death in the acute respiratory distress syndrome. N Engl J Med 2002, 346:1281-1286.

364. Marshall BE, Marshall C, Frasch F, Hanson CW: Role of hypoxic pulmonary vasoconstriction in pulmonary gas exchange and blood flow distribution. 1. Physiologic concepts. Intensive Care Med 1994, 20:291-297.

365. Tomashefski JF Jr, Davies P, Boggis C, Greene R, Zapol WM, Reid LM: The pulmonary vascular lesions of the adult respiratory distress syndrome. Am J Pathol 1983, 112:112-126.

doi:10.1186/cc9264

Cite this article as: Price et al.: Pulmonary vascular and right ventricular dysfunction in adult critical care: current and emerging options for management: a systematic literature review. Critical Care 2010 14:R169.

\section{Submit your next manuscript to BioMed Central and take full advantage of:}

- Convenient online submission

- Thorough peer review

- No space constraints or color figure charges

- Immediate publication on acceptance

- Inclusion in PubMed, CAS, Scopus and Google Scholar

- Research which is freely available for redistribution 